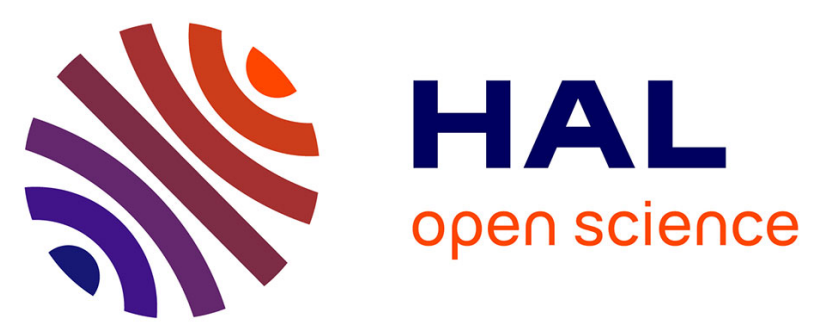

\title{
Development and application of a methodology for screening, on the basis of the carcinogenic (H7), toxic for reproduction (H10) and mutagenic (H11) criteria of the latest European legislation, hazardous vs. non-hazardous sediments to be disposed of on land
}

Christophe Mouvet

\section{To cite this version:}

Christophe Mouvet. Development and application of a methodology for screening, on the basis of the carcinogenic (H7), toxic for reproduction (H10) and mutagenic (H11) criteria of the latest European legislation, hazardous vs. non-hazardous sediments to be disposed of on land. Journal of Soils and Sediments, 2011, 11 (7), pp.1292-1307. 10.1007/s11368-011-0404-x . hal-00681123

HAL Id: hal-00681123

https://hal-brgm.archives-ouvertes.fr/hal-00681123

Submitted on 21 Mar 2012

HAL is a multi-disciplinary open access archive for the deposit and dissemination of scientific research documents, whether they are published or not. The documents may come from teaching and research institutions in France or abroad, or from public or private research centers.
L'archive ouverte pluridisciplinaire HAL, est destinée au dépôt et à la diffusion de documents scientifiques de niveau recherche, publiés ou non, émanant des établissements d'enseignement et de recherche français ou étrangers, des laboratoires publics ou privés. 


\title{
SEDIMENTS, SEC 5 • SEDIMENT MANAGEMENT • RESEARCH ATICLE
}

\author{
Development and application of a methodology for screening, on the basis of the carcinogenic (H7), toxic \\ for reproduction (H10) and mutagenic (H11) criteria of the latest European legislation, dredged sediments \\ to be disposed of on land
}

\section{Christophe Mouvet}

Received: 14 October 2010 / Accepted: \#\# June 2011

(C) Springer-Verlag 2011

Responsible editor: Sabine Apitz

\author{
C. Mouvet $(\square)$ \\ BRGM, Environment and Process Division, Avenue C. Guillemin, BP 36009, 45060 Orléans cédex 2, France \\ e-mail: c.mouvet@brgm.fr
}

\section{( $\bowtie)$ Corresponding author:}

Tel: +33238643908

Fax: +33238643963

e-mail: c.mouvet@brgm.fr

\begin{abstract}
Purpose According to the European List of Wastes, dredged sediments are either hazardous or non hazardous waste. Our first purpose was to develop a methodology for applying the criteria H7 (Carcinogen, C), H10 (toxic for reproduction, R) and H11 (mutagenic, M) of EU Legislation to the results of Routine Sediment Monitoring Networks - RSMNs. Criteria H7, H10 and 11 are the only ones for which quantitative data are available in RSMNs. The second purpose was to apply, with a perspective of sediment management, the methodology to data sets from RSMNs.

Materials and methods The data sets held up to 4,012 inland and 1,362 marine sediments for trace elements, and up to 2,774 inland and 952 marine sediments for organic micropollutants. Based on i) the trace elements analysed in RSMNs, ii) a literature review of aqueous solubility of the dangerous inorganic substances (EU list), and iii) a literature review of trace elements speciation in sediments, twelve inorganic dangerous substances with CRM properties were selected. For each substance, the threshold concentrations corresponding to a hazardous waste were then transformed into threshold total trace element contents. For the organic micropollutants, the list of dangerous substances considered was imposed by the content of RSMNs data bases, and the threshold values were directly taken from the waste regulation. The statistical distributions of the data set values were then compared to the threshold values.
\end{abstract}

Page 1 sur 27 
Results and discussion Exceedances of the threshold values were observed for all trace elements and were

\section{Introduction}

Nowadays, the increased awareness of the need for sustainable development leads many nations to direct their transportation policies to more environmentally friendly means, like inland water transport. For instance, the French nationwide consultation on sustainable development (“Le Grenelle de l'Environnement”), involving all stakeholders, identified transport as an area where major improvements can be achieved, notably through the promotion of marine and fluvial transport (Le Grenelle 2007; Assemblée Nationale 2008). As a result, dredging of waterways required to increase the depth and to keep the channels navigable will gain in importance, as will the amounts of dredged sediments to be managed (Torres et al. 2009).

Dredged sediments are typical "mirror entries" of the European List of Wastes (European Commission, 2000): they are either hazardous or non hazardous, depending on a series of criteria, including their possible carcinogenic (H7), toxic for reproduction (H10) and mutagenic (H11) character (European Commission, 2008). The H14 criterion (ecotoxicity) is not considered here since i) there is no standardised battery of ecotoxicity tests for wastes at EU level and ii) data on ecotoxicity in Routine marine and inland Sediment Monitoring Networks RSMNs are extremely sparse. Whether dredged sediment is classified as a hazardous or not hazardous waste is of major concern for its later management. Hazardous wastes have to be treated or/and stored in specialised waste disposal facilities (with added cost), whereas non hazardous wastes may be re-used (possible income, Cornelis et al 2006).

The first purpose of this paper was to develop a methodology for applying the H7, H10 and H11 criteria in the case of sediments likely to be dredged and disposed of on land. These criteria (the only ones for which quantitative data are available in RSMNs) were chosen as part of the overall assessment of environmental hazards (including human health) that may be caused by the management of dredged sediments. 
The second purpose was to apply the methodology to extensive and intensive data sets from French and Belgian routine monitoring programs of inland and marine sediments, and to assess the implications of this application in terms of management options of dredged sediments.

\section{Material and methods}

\subsection{Data sets available and statistical analysis}

Six data sets were examined: the year 2007 campaign of the French Surveillance Control Monitoring Network (FSCMN) set up in compliance with the European Union Water Framework Directive, the October 2005 through March 2008 samplings of the French navigable waterways (FNW; Northern, Eastern and Central France), the March 1998 through August 2007 samplings of the Walloon navigable waterways (WNW), the September 2001 through August 2008 samplings of the Walloon non-navigable waterways (WNNW), the year 1993 through 2005 samplings of the French National Network of Observation of Marine Environment Quality (RNO), and the March 1998 through May 2008 samplings of the National network of Monitoring of Marine Harbours (REPOM). The data sets VNF, WNW and REPOM hold samples originating from areas severely impacted by ancient and/or present industrial activities.

The data on trace elements (As, $\mathrm{Cd}, \mathrm{Co}, \mathrm{Cr}, \mathrm{Ni}, \mathrm{Pb}, \mathrm{Zn}$ ) from FSCMN, FNN, WNW and WNNW were merged in one single data base because samples are all of inland origin and the list of elements analysed is identical. For the organic micropollutants, the data of FNN, WNN and WNNW were grouped together, whereas the FSCMN data bas was analysed separately because it includes a list of substances (see Table 1 of Electronic Supplementary Material) far more extensive than the other data bases. The two data bases with sediments from marine origin were merged to increase the number of samples considered in the statistical analysis.

All data refer to the sediment fraction $<2 \mathrm{~mm}$. The procedures used for extractions and analyses by the various networks are international ISO (e.g., 11885, ISO 2009; 15586, ISO 2004), EPA (e. g. 3050 B, 3051, 3052; EPA 2009 a to c) or AFNOR (e.g., X 33-012, AFNOR 2000; X 31-147, AFNOR 1996) standard procedures. It was not possible to collect information on quality control procedures applied by all the laboratories involved in the six different monitoring programs covering two countries. The resulting possible bias and errors were considered less important than the interest of addressing very large data bases with sediments of contrasted origins and contamination levels.

The data treatment consisted in replacing all values < detection limit (DL) by half the value of DL (European Commission 2009 a; European Commission 2006; Farnham et al. 2002; Ministère Québécois du Développement durable de l'Environnement et des Parcs 2009). Other statistical methods can be preferred over such a simple approach (Helsel and Hirsch 1991) but they were not applied here since our work did not focus on the lowest values, but on the most frequent and highest ones. Indeed, it is mainly for the estimation of the low values of statistical distributions that the simple systematic substitution is likely to introduce a bias (Caudill et al. 2007). No bias is introduced for estimating the median values or the $95^{\text {th }}$ percentile as long as the percentage of values $<$ DL does not exceed $1 / 3$ or $2 / 3$ of the total population, respectively (Caudill et al. 2007). For the parameters considered here, the percentages of values < DL never reached levels likely to introduce a bias in the statistical examination of the high values, which are those of concern in the assessment of the hazardous character of the sediments. Finally, the comparison between several procedures for taking into account values < 
DL shows that the replacement by DL/2 gives better results than the replacement by DL or zero (Farnham et al. 2002).

Descriptive statistical analyses were conducted with the XLSTAT 20084.01 software. Besides scattergram diagrams, linear correlations between pairs of trace elements were examined (Pearson correlation coefficient, and slope of the correlation) for the hazardous substances identified as possibly present in sediments and including two trace elements $\left(\mathrm{ZnCrO}_{4}, \mathrm{PbHAsO}_{4}, \mathrm{PbCrO}_{4}\right.$; see 2.2.2). If the measured total trace elements concentrations correspond only (or mainly) to these dangerous substances, a hypothesis maximizing the potential hazard, the linear correlations between the concentrations $(\mathrm{mg} / \mathrm{kg})$ of pairs of trace elements should be highly significant (0.01 level) with a slope of the correlation (or median ratio of concentrations) equal (or very close) to the ratio of atomic mass of the two elements considered, i. e.1.26 for the correlation $\mathrm{Zn} / \mathrm{Cr}, 0.8$ for $\mathrm{Cr} / \mathrm{Zn}, 2.77$ for $\mathrm{Pb} / \mathrm{As}, 0.36$ for $\mathrm{As} / \mathrm{Pb}, 3.99$ for $\mathrm{Pb} / \mathrm{Cr}$, and 0.25 for the correlation $\mathrm{Cr} / \mathrm{Pb}$. Such an indirect estimation of the possible presence of dangerous inorganic substances is made necessary by the fact that neither chemical techniques for operationally-defined speciation of metals (Tessier et al. 1979), nor more specific spectroscopic techniques (O’Day et al. 2000; Panfili et al. 2005; Peltier et al. 2005) enable the identification of specific substances.

\subsection{Short update on the European Union legislative framework on wastes and sediment management}

The Directive 2008/98 (European Commission 2008 a) on waste repeals the previous EU directives. Dredged sediments are classified as waste; their management has to be in accordance with the Waste Hierarchy and depends on their content of dangerous substances. Recovery and valorisation of the materials could be one of the management options. Article 6 of Directive 2008/98 defines the end-of-waste status, applicable to sediments, which could therefore be bound by the Chemical Substances and Preparations regulation (EC) 1907/2006 (so called REACH) and will need to pass the test of H7, H10 and H11 criteria. In parallel, the 25-26 September 2008 meeting of the Competent Authorities for the implementation of REACH concluded "...As soon as a material 'ceases to be waste' in a recovery process, REACH requirements apply in principle as to any other material..." (European Commission, 2008 b). The same group provides updated definitions of "substances of Unknown or Variable composition, Complex reaction products or Biological material" and "articles" that fall under REACH legislation and clearly apply to sediments. Finally, the working group for the amendment of the European waste list (summary record of the meetings held on 5 and 6 November 2009, unpublished document 21/12/2009, GW/amp-env.g.2(2009)436598) is discussing the definition of $\mathrm{H}$ criteria to be applied to wastes, not only substances and preparations.

The application to sediments of the generic concentrations of $\mathrm{H} 7, \mathrm{H} 10$ and $\mathrm{H} 11$ related to the regulation of Classification, Labelling and Packaging of dangerous substances (European Commission 2008 c) is therefore in line with the up-to-date EU legislation.

\subsection{Selection of the dangerous substances with CRM properties possibly present in sediments}

The list and classification of dangerous substances according to H7, H10 and H11 is updated annually by the European Commission; the version used in this work is dated of January 2009 (European Commission 2009 b). Linking this list with the threshold concentrations set for hazardous wastes leads for each substance to the threshold concentration above which the waste will be classified as hazardous. For the organic micropollutants, 
the procedure is straightforward since the analyses available for sediments relate indeed to the substances monitoring programs provide data on total trace elements concentrations, not on the substance in which the element may be included. The first step of our work was therefore to identify for the trace elements analysed in the data sets available ( $\mathrm{As}, \mathrm{Cd}, \mathrm{Cr}, \mathrm{Co}, \mathrm{Cu}, \mathrm{Hg}, \mathrm{Ni}, \mathrm{Pb}, \mathrm{Zn}$ ) and included in dangerous substances (all elements but $\mathrm{Cu}$ and $\mathrm{Hg}$ that are not included in any of the dangerous substances from the EU list, European Commission 2009 b), which dangerous substances were most likely to be present in sediments. This step was taken through a literature review on aqueous solubility and on metal speciation in sediments.

\subsubsection{Literature review of aqueous solubility of the dangerous inorganic substances including trace elements} analysed in routine sediments monitoring programs (Table 1)

For arsenic, the high aqueous solubility of arsenic oxides and arsenic acid, and the possible biodegradation of the ethyl groups of triethyl arsenate result in $\mathrm{As}_{2} \mathrm{O}_{5}, \mathrm{As}_{2} \mathrm{O}_{3},\left(\mathrm{C}_{2} \mathrm{H}_{5} \mathrm{O}\right)_{3} \mathrm{AsO}$ and $\mathrm{H}_{3} \mathrm{AsO}_{4}$ being excluded of the substances to be considered in sediments. By contrast, $\mathrm{pH}$-pe equilibrium modelling with data from river sediments shows $\mathrm{HAsO}_{4}{ }^{2-}$ to be stable for $\mathrm{pH}>6,8$ and redox potential > $130 \mathrm{mV}$ (Blute et al. 2009); $\mathrm{PbHAsO}_{4}$ will therefore be selected as substance of relevance for arsenic (and lead).

For $\mathrm{Cd}$, the low aqueous solubility of sulphide and oxide leads to the two substances being considered as possibly present in sediments.

For cobalt, the very low aqueous solubility of carbonate may lead to $\mathrm{CoCO}_{3}$ being present in sediments.

Chromate is a frequent constituent of CRM substances. However, calcium, potassium, sodium, strontium and ammonium chromates have such high a high aqueous solubility that their presence in sediments is very unlikely. The case of zinc and lead chromates is quite different; only slightly soluble in water, they can possibly be present in the solid fraction of sediments. Indeed, the presence of poorly soluble chromates in some sediments can not be ruled out (Lespagnol 2003; Barnhart 1997) and hexavalent chromium is naturally present in the mineral $\mathrm{PbCrO}_{4}$ (Zayed and Terry 2003). Zinc and lead chromates will therefore be included for the evaluation of the CRM properties of sediments in link with the total chromium content.

For nickel, the oxide, hydroxide and carbonate should be considered since their aqueous solubility is very low. Nickel trioxide is a very strong oxidant (INRS 2009) that would be reduced by the organic matter and sulphides (or other reduced species) of sediments; it will therefore not be considered further.

For lead, in addition to $\mathrm{PbHAsO}_{4}$ and $\mathrm{PbCrO}_{4}, \mathrm{~Pb}_{2}(\mathrm{PO} 4)_{3}$ will be considered even though pure metal phosphate minerals are unlikely to form under the environmental conditions prevailing in most soils and sediments (Martinez et al. 2004). By contrast, the highly explosive and sensitive nature of lead azide makes its presence in sediment highly unlikely.

For zinc, chromate is the only reported CRM substance and it will be taken into consideration since poorly soluble chromates can be present in some sediments (Lespagnol 2003; Barnhart 1997).

\subsubsection{Literature review on the speciation in sediments of trace elements analysed in routine sediment monitoring programs}

Most papers reviewed rely on the sequential extraction developed by Tessier (Tessier et al. 1979), modified to various degrees, mostly for As (e.g., Blute et al. 2009). A few papers report results from spectroscopic methods 
(O'Day et al. 2000; Panfili et al. 2005; Peltier et al. 2005). The detailed outcome of the literature review is available as Table 2 in the Electronic Supplementary Material; a summary is presented below.

Arsenic The most recent studies with the extraction procedure most adapted to As show the prevalence of the exchangeable (Bluet et al. 2009) or sulphide fraction (Jay et al. 2005). The other studies, which rely on a more standard Tessier's protocol, associate most of As to the operationally defined "oxides" or "residual fraction". However, since arsenic oxides have very high aqueous solubility (see Table 1), the fraction of As extracted from sediments using the reagents targeting the "oxide" fraction are unlikely to be $\mathrm{As}_{2} \mathrm{O}_{5}$ or $\mathrm{As}_{2} \mathrm{O}_{3}$, substances of possible interest for CRM considerations. The other fractions from chemical extraction do not allow to exclude the possible contribution of lead arsenate to the total As content of sediments. Based on the information from Table 1 and from the speciation studies, $\mathrm{PbHAsO}_{4}$ is selected as the CRM substance to be considered for As.

Cadmium The speciation is highly variable according to the sediments studied. The maximum relative contributions are 77\%, 47\% and 42\% for the organic matter fraction (Martin et al. 1996), the hydroxide/oxide fraction (Pardo et al. 1990) and the sulphide fraction (Loska and Wiechula 2002), respectively. Spectroscopic methods applied to highly contaminated estuarine sediments (244 and $764 \mathrm{mg} / \mathrm{kg}$ ) indicate that all of the Cd is present as sulphides (O'Day et al. 2000). Combining the information from Table 1 with the speciation studies leads to the selection of $\mathrm{CdS}$ and $\mathrm{CdO}$ as the CRM substances considered for $\mathrm{Cd}$.

Cobalt The possibility of cobalt to be associated with the carbonate phase of marine and freshwater sediments is indicated by various studies (Akcay et al. 2003; Baruah et al. 1996; Yuan et al. 2004). $\mathrm{CoCO}_{3}$ can therefore be considered as a relevant CRM substance for cobalt in sediments. It must be noted however that the relative contribution of the carbonate phase to the total Co content of sediments seems limited to $10 \%$.

Chromium Two studies on coastal sediments (some highly contaminated, $1050 \mathrm{mg} / \mathrm{kg}$ ) indicate the fraction associated with Fe and Mn oxides as dominant (60\%), with the "organic matter" fraction being also a significant contributor (Graham et al. 2009; Lam et al. 1997). Several studies of lake sediments also indicate a significant contribution of the oxide (20-36\%) and organic matter (10-40\%) phases (Akcay et al. 2003; Fytianos and Lourantou 2004). Spectroscopic methods applied to an anoxic estuarine sediment shows chromium to be exclusively bound to oxygen atoms (O'Day et al. 2000). All the results from the reviewed speciation studies support the initial choice, based on aqueous solubility (see Table 1), of $\mathrm{ZnCrO}_{4}$ and $\mathrm{PbCrO}_{4}$ as the chromatebased CRM substances most relevant for the purpose of the present study.

Nickel Based on the chemical extraction results $\mathrm{NiCO}_{3}$ can be considered as a CRM substance possibly present in sediments, carbonates contributing to $16 \%$ (Pardo et al. 1990) or 34\% (Lam et al. 1997) of the total Ni. The speciation studies do not provide information that would remove nickel hydroxide, monoxide and trioxide from the list of CRM substances possibly present in sediments. Four CRM substances holding Ni will therefore have to be considered.

Lead In most lake sediments studied (Tokalioglu et al. 2000; Fytianos and Lourantou 2004), in saltmarshes (Mortimer and Rae 2000; Reboreda and Caçador 2007) and in contaminated marine sediments (Yuan et al. 2004), the organic/sulphide fraction is dominant. However, in a contaminated ( $\mathrm{Pb}=213$ to $1269 \mathrm{mg} / \mathrm{kg}$ ) reduced estuarine sediment, spectroscopic methods indicate that $\mathrm{Pb}$ is bound to oxygen atoms, not to organic matter nor sulphides (O'Day et al. 2000). In canal and river sediments, the oxide and residual phases have been reported as the major constituents of the total lead content (Akcay et al. 2003; Baruah et al. 1996; Galvez-Cloutier and Dubé

Page 6 sur 27 
1998; Savonina et al. 2006). The reported association of lead with oxide fraction or oxygen atoms confirm the

Zinc According to the sediment studied, most of $\mathrm{Zn}$ is associated with the fraction operationally-defined as hydroxides/oxides (Akcay et al. 2003) or sulphides (Panfili et al. 2000; Tokalioglu et al. 2000; O’Day et al. 2000; Peltier et al. 2005) or residual (Isaure et al. 2001; Yuan et al. 2004). The contribution of $\mathrm{ZnCrO}_{4}$ to a fraction of Zn being present in the operational fraction "hydroxides/oxides" can not be totally excluded, and zinc chromate will be considered in the following data analysis.

\subsection{Threshold values selected for the data analysis}

For each inorganic CRM substance identified as possibly present in sediments, the threshold value associated to its classification into category 1, 2 or 3 of criterion C, M or R, has been transformed into the corresponding trace element total concentration (Table 2), based on the assumption that all of the trace element is present solely as the substance considered. For instance, the limit value in a non hazardous waste for zinc chromate, $\mathrm{ZnCrO}_{4}$, being $1000 \mathrm{mg} / \mathrm{kg}(0.1 \%$, carcinogenic category 1$)$, the limit value for total zinc, considered present solely as $\mathrm{ZnCrO}_{4}$, is $361 \mathrm{mg} / \mathrm{kg}\left(1000 \mathrm{mg} / \mathrm{kg}\right.$ * atomic mass of $\mathrm{Zn} / \mathrm{molecular}$ weight of $\left.\mathrm{ZnCrO}_{4}\right)$. For $\mathrm{Cd}, \mathrm{Cr}, \mathrm{Ni}$ and $\mathrm{Pb}$, more than one CRM substance was identified by the literature review; the most stringent threshold value (substance in bold type, see Table 2) will be considered. This overall procedure is clearly very conservative.

\section{Results and discussion}

3.1 Organic substances with CRM properties in the data set from the French Surveillance Control Monitoring Network (FSCMN)

This data set, covering all of French inland surface waters, is the most comprehensive one regarding the number of substances analysed (168; see Table 1 of the Electronic Supplementary Material) and the number of samples (up to 1630 , depending on the substance).

The substances with CRM properties quantified in at least $0.5 \%$ of the data set consist of 6 polycyclic aromatic hydrocarbons $(\mathrm{PAH}), 1$ phthalate, 1 aromatic hydrocarbon, 1 nonylphenol, 2 herbicides and 4 chlorinated aliphatics (Table 3). None of these are however classified as known CRM (category 1), seven are suspected CRM (category 2), and eight are classified as possible CRM (category 3).

The maximum concentration of CRM substances, $62 \mathrm{mg} / \mathrm{kg}$ for benzo(a)pyrene, remains 16 times lower than the threshold concentration above which the sediment would be classified as « hazardous ». Six other PAHs show maximum concentrations of the same order of magnitude. Toluene is one order of magnitude lower than benzo(a)pyrene and has a threshold value 50 times greater, so that the safety margin for toluene is a factor of 33 333. The maximum ethyl hexyl phthalate (EHP) concentration is of the same order of magnitude as for benzo(a)pyrene, but the threshold concentration for EHP is 5 times higher so that the maximum value is 278 times below the threshold. The maximum for 4 para-nonylphenol is of the same order as the PAHs, but its threshold value 50 times greater, so that the safety margin is a factor of 962 . The maximum concentrations observed for herbicides and chlorinated aliphatics are between 100,000 and 1,000,000 times lower than the threshold value. Since the threshold value is not approached for any organic substance, the scattergrams of the concentrations are not presented. 
3.2 Organic substances with CRM properties in the data set from the inland sediments of Northern, Eastern and Central French navigable waterways, and Walloon navigable and non-navigable waterways

The data from the Walloon non navigable waterways could not be merged with the other inland data sets because they are presented by groups of substances, not as individual substances. Indeed, the results for PAHs are expressed as the sum of the 16 PAHs from the EPA list, and the results of benzene and toluene are not available individually (the value reported is the sum of benzene, toluene, ethylbenzene and xylenes). As for chlorinated pesticides, the results are expressed as the sum of hexachlorobenzene (HCB; carcinogenic C2), aldrin (C3), dieldrine (C3), endrine, isodrine, lindane, heptachlor epoxide, 4,4 DDE, 2,4 DDT and 4,4 DDT. For the interpretation of the data from the Walloon non navigable waterways, the total concentration of each group of substances was assumed to be the concentration of the most dangerous CRM category of the group.

The maximum concentration is $35.9 \mathrm{mg} / \mathrm{kg}$ for chrysene (Table 4), a value 28 times lower than the threshold. The other 5 PAHs analysed, and toluene, show maximum concentrations of the same order of magnitude. Benzene and hexachlorobenzene are 2 orders of magnitude lower than the PAHs. None of these substances is therefore likely to pose a CRM hazard in the sediments sampled.

The concentrations of the chlorinated pesticides are similar to literature data, $0.003 \mathrm{mg} / \mathrm{kg}$ for atrazine (Holvoet et al. 2007) and $0.033 \mathrm{mg} / \mathrm{kg}$ for DDTs (Liu et al. 2008). Higher concentrations of chlorinated pesticides are reported in the literature, e.g., $0.45 \mathrm{mg} / \mathrm{kg}$ for lindane (Villaverde et al. 2008) and $0.81 \mathrm{mg} / \mathrm{kg}$ for the sum of 18 substances (Malik et al. 2009), but even these extreme values remain far below the threshold for these substances. Based on the threshold values set by the EU directive on wastes, the CRM hazards resulting from pesticides in inland sediments can therefore be disregarded.

\subsection{Organic substances with CRM properties in the data set from the French marine sediments monitoring networks}

Six PAHs are analysed in both RNO and REPOM networks, while the chlorinated pesticides are analysed only in the RNO network.

The maximum concentration of the CRM organic substances analysed (Table 5) is much lower (37 times, chrysene) than the threshold concentration. The two chlorinated pesticides pose even less problem, with a safety margin of a factor 27778 for pp'-DDT and 833333 for $\alpha-\mathrm{HCH}$. The organic contaminants with CRM properties analysed in the French marine sediments do not get anywhere close to the threshold value that would lead to the classification of the sediments as hazardous wastes on the basis of the H7, H10 and H11 criteria.

\subsection{Inorganic substances with CRM properties in the data set from the French marine sediments monitoring networks (RNO + REPOM)}

Total trace element concentrations exceeding the threshold concentration are observed for $\mathrm{Cr}, \mathrm{Pb}$ and $\mathrm{Zn}$ (Table 6). It must be recalled that the threshold concentration is the total trace element concentration that would lead to the classification of the sediment as hazardous waste if the total concentration resulted entirely from the substance with CRM properties identified as possibly present in sediments.

The statistical distributions of $\mathrm{Cr}, \mathrm{Pb}$ and $\mathrm{Zn}$ concentrations illustrated by scattergrams in Fig. 1 shows that the proportion of samples exceeding the threshold is greatest for $\mathrm{Zn}(9 \%)$, less for $\mathrm{Cr}(1.2 \%)$, and lowest for $\mathrm{Pb}$ (0.07\%).

Page 8 sur 27 
The interpretation of the data will consider the uncertainty associated with the extraction and analysis procedures. The precision of trace elements concentrations determined in reference materials varies according to the element, and, for each element, generally decreases with increasing concentrations (Table 7). The reported reproducibility will be used in the data treatment to ensure that only the samples with concentrations exceeding the threshold concentration by more than the expected average variability will be considered as really posing a possible CRM hazard.

For the samples with $\mathrm{Cr}$ concentrations greater than the threshold of $161 \mathrm{mg} / \mathrm{kg}$, the hypothesis of $\mathrm{Cr}$ being present mainly as $\mathrm{Pb}$ or $\mathrm{Zn}$ chromate was checked by looking at the correlations between $\mathrm{Cr}$ and $\mathrm{Zn}$, and $\mathrm{Cr}$ and $\mathrm{Pb}$ concentrations. The linear correlations are not statistically significant at the 5\% level (data not shown). For $\mathrm{Cr}$ and $\mathrm{Pb}$, the ratio between $\mathrm{Cr}$ and $\mathrm{Pb}$ concentrations that would result from all $\mathrm{Cr}$ being present as $\mathrm{PbCrO}_{4}, 0.25$, is not observed for any sample. Actually, the mean ratio between $\mathrm{Cr}$ and $\mathrm{Pb}$ concentrations for the 14 samples with $\mathrm{Cr}>161 \mathrm{mg} / \mathrm{kg}$ is 12.3 , the median is 7.5 , and no sample shows a ratio within $50 \%$ of the threshold ratio ( $50 \%$ is taken here as an estimate of the cumulated uncertainties linked to the use of ratios of concentrations). For $\mathrm{Cr}$ and $\mathrm{Zn}$, the theoretical ratio between concentrations that would result from all $\mathrm{Cr}$ being present as $\mathrm{ZnCrO}_{4}$ is 0.17 ; the mean ratio observed for the 14 samples with $\mathrm{Cr}>161 \mathrm{mg} / \mathrm{kg}$ is 3.4 , the median is 1.6 , and the only sample with a ratio, 0.19 , within $50 \%$ of the theoretical value has a total $\mathrm{Cr}$ concentration of $163 \mathrm{mg} / \mathrm{kg}$ which falls in the $12 \%$ uncertainty for $\mathrm{Cr}$ determinations in that range of concentrations in sediments (see Table 7). These observations strongly, albeit indirectly, suggest that in the marine sediments where $\mathrm{Cr}$ exceeds the threshold, $\mathrm{Cr}$ is not present as lead or zinc chromate. The hazard due to $\mathrm{Cr}$ present as $\mathrm{PbCrO}_{4}$ or $\mathrm{ZnCrO}_{4}$ can therefore be disregarded.

The same type of data analysis must also be conducted for the samples that exceed $\mathrm{Zn}$ or $\mathrm{Pb}$ thresholds.

For $\mathrm{Pb}$, only one sample exceeds $597 \mathrm{mg} / \mathrm{kg}$. Its corresponding $\mathrm{Cr}$ concentration, $391 \mathrm{mg} / \mathrm{kg}$, yields a $\mathrm{Pb} / \mathrm{Cr}$ mass ratio of 1.5 that does not satisfy the hypothesis of $\mathrm{Pb}$ being fully present as $\mathrm{PbCrO}_{4}$ (the $\mathrm{Pb} / \mathrm{Cr}$ mass ratio in $\mathrm{PbCrO}_{4}$ is 3.99). For the sample with $\mathrm{Pb}>597 \mathrm{mg} / \mathrm{kg}$, the corresponding As concentration, $32 \mathrm{mg} / \mathrm{kg}$, yields a $\mathrm{Pb} / \mathrm{As}$ mass ratio of 18.7 that does not, by far, satisfy the hypothesis of $\mathrm{Pb}$ being entirely present as $\mathrm{PbHAsO}_{4}$ (the $\mathrm{Pb} / \mathrm{As}$ mass ratio in $\mathrm{PbHAsO}_{4}$ is 2.77). In this outlier sample, $\mathrm{Pb}$ is therefore not present as $\mathrm{PbCrO}_{4}$ nor $\mathrm{PbHAsO}_{4}$ and no CRM hazard linked to $\mathrm{Pb}$ can be attributed to the sample.

For the 120 samples where $\mathrm{Zn}$ exceeds the threshold, the hypothesis of $\mathrm{Zn}$ being present as $\mathrm{ZnCrO}_{4}$ requires the ratio of $\mathrm{Zn}$ to $\mathrm{Cr}$ concentrations to be 1.26. Now, the linear correlation between $\mathrm{Zn}>395$ and $\mathrm{Cr}$ is not statistically significant at the 5\% level (data not shown), and the mean ratio of $\mathrm{Zn} / \mathrm{Cr}$ concentrations in samples with $\mathrm{Zn}>361 \mathrm{mg} / \mathrm{kg}$ is 14 , the median being 8.2 . The only sample showing a ratio $\mathrm{Zn} / \mathrm{Cr}$, 1.2 , within $50 \%$ of the theoretical value; has a total $\mathrm{Zn}$ concentration of $406 \mathrm{mg} / \mathrm{kg}$, hardly greater than the $\mathrm{Zn}$ threshold value of $395 \mathrm{mg} / \mathrm{kg}$. The $14 \%$ uncertainty on $\mathrm{Zn}$ determinations in sediments for this range of concentrations (see Table 7) means that the actual concentration may well be in fact lower than the threshold value. Therefore, it is not quite sure that this given sample satisfies the criteria leading to its classification as possibly hazardous on the basis of carcinogen property category 1 linked to $\mathrm{ZnCrO}_{4}$.

\subsection{Inorganic substances with CRM properties in the data set from the French and Walloon inland sediments monitoring programs}

Page 9 sur 27 
To various degrees, the threshold value of the CRM substance considered is exceeded for all the trace elements

(Table 8). The greatest relative exceedance $(\mathrm{R}=$ maximum value/threshold value) is observed for $\mathrm{Zn}$, with $\mathrm{R}=$ 395; the smallest relative exceedances are observed for $\mathrm{As}, \mathrm{Co}, \mathrm{Cr}$ and $\mathrm{Ni}$, with $\mathrm{R}=4.7$ to 5.0. The proportion of values exceeding the threshold ranges from $0.1-0.2 \%$ for $\mathrm{As}, \mathrm{Cd}$ and $\mathrm{Ni}$, to $27 \%$ for $\mathrm{Zn}$. The detailed distribution of values is illustrated in Fig. 2.

For $\mathrm{Cd}$, Co and $\mathrm{Ni}$, the analytical data available do not enable to assess if the rare exceedances are actually due to the presence of the CRM substance on which the threshold value is based. An indirect reasoning based on the literature review on metal speciation in sediments will therefore be applied. The maximum relative exceedance observed for $\mathrm{Co}$ is equal to 5 , whereas a value of 10 would be needed to suggest a $\mathrm{CRM}$ hazard due to $\mathrm{CoCO}_{3}$ since the maximum contribution of the carbonate fraction reported in speciation studies of Co in sediments is 10\% (Akcay et al. 2003). By contrast, the maximum relative exceedances observed for $\mathrm{Cd}$ and $\mathrm{Ni}$ (9 and 5 , respectively) may actually correspond to a CRM hazard since $\mathrm{CdS}$ and $\mathrm{NiCO}_{3}$, the $\mathrm{CRM}$ substance considered to set the threshold, may represent $100 \%$ of the total Cd (O'Day et al. 2000) and 16-34\% of the total Ni (Lam et al. 1997; Pardo et al. 1990) concentration in the sediment. For $\mathrm{Ni}$, considering 34 or $16 \%$ as the possible contribution of $\mathrm{NiCO}_{3}$ to the total Ni concentration, only 3 or 0 samples would constitute a possible CRM hazard resulting from $\mathrm{NiCO}_{3}$. For $\mathrm{Cd}$, the 8 samples exceeding the threshold value may constitute a CRM hazard resulting from the substance $\mathrm{CdS}$ as defined by the legislation on wastes. The actual bioavailability of CdS and $\mathrm{NiCO}_{3}$ in sediments is however most likely to be much lower than the pure substances for which the CRM hazards have been assessed. Furthermore, once sediments are exposed to aerobic conditions such as during resuspension or ripening on land, metal sulphides are known to be prone to oxidation which may result in the progressive disappearance of substances such as CdS (Chapman et al. 1998, di Toro et al. 1992, du Laing et al. 2007, O’Day et al. 1998). Sediment acidification resulting from oxidation of organic matter and sulphides (Petersen et al. 1997) may also lead to transformation of carbonate forms such as $\mathrm{NiCO}_{3}$. The real CRM hazard posed by the possible presence of CdS ( 8 samples, $0.2 \%$ of the total number of samples) and $\mathrm{NiCO}_{3}(3$ samples, $0.08 \%$ of the total number of samples) in sediments that would be managed as wastes is therefore very likely to be negligible.

For $\mathrm{As}, \mathrm{Cr}, \mathrm{Pb}$ and $\mathrm{Zn}$, the analysis of the correlations between pairs of elements can give an insight into the possibility that the CRM substances considered for each of these 4 trace elements represent actually a significant part of the total metal concentrations.

\subsubsection{Cr in $\mathrm{ZnCrO}_{4}$}

For the 98 samples where $\mathrm{Cr}>161 \mathrm{mg} / \mathrm{kg}$, the slope of the linear correlation (significant at the $0.1 \%$ level) between $\mathrm{Cr}$ and $\mathrm{Zn}$ concentrations is 0.03 (Fig. 3) and the median ratio between $\mathrm{Cr}$ and $\mathrm{Zn}$ concentrations is 0.2 , whereas the two parameters should equal 0.8 if all the total $\mathrm{Cr}$ was present as $\mathrm{ZnCrO}_{4}$. However, seventeen samples show a ratio $\mathrm{Cr} / \mathrm{Zn}$ within $50 \%$ of the theoretical value, and twelve of them have a $\mathrm{Cr}$ concentration greater than the $\mathrm{Cr}$ threshold $+15 \%$ (15\% is taken here as common analytical uncertainty on $\mathrm{Cr}$ determinations in sediments, see Table 7). These 12 samples ( $0.4 \%$ of the total number of samples) may be considered as posing a possible hazard due to the presence of $\mathrm{Cr}$ as $\mathrm{ZnCrO}_{4}$.

\subsection{2 $\mathrm{Zn}$ in $\mathrm{ZnCrO}_{4}$}


For the 877 samples where $\mathrm{Zn}>361 \mathrm{mg} / \mathrm{kg}$, the slope of the linear correlation (significant at the $0.1 \%$ level) whereas a value of 1.3 is expected for samples in which all $\mathrm{Zn}$ would be present as $\mathrm{ZnCrO}_{4}$. Only 4 samples are within $50 \%$ of the theoretical ratio of 1.3 , and only 3 of these 4 have $\mathrm{Zn}$ concentrations exceeding the threshold total $\mathrm{Zn}$ concentration by $20 \%$ or more. The possible CRM hazard linked to $\mathrm{ZnCrO}_{4}$ is therefore limited to $0.09 \%$ of the 3,412 sediment samples analysed.

\subsection{3 $\mathrm{Pb}$ in $\mathrm{PbCrO}_{4}$}

For the 80 samples where $\mathrm{Pb}>597 \mathrm{mg} / \mathrm{kg}$, the slope of the linear correlation (significant at the $0.1 \%$ level) between $\mathrm{Pb}$ and $\mathrm{Cr}$ concentrations is -2.1 (Fig. 5) and the median ratio between $\mathrm{Pb}$ and $\mathrm{Cr}$ concentrations is 13 , whereas it would be 4 for a sample with all $\mathrm{Pb}$ present as $\mathrm{PbCrO}_{4}$. Four samples exhibit a $\mathrm{Pb} / \mathrm{Cr}$ ratio within $50 \%$ of the theoretical value, but none exceeds the threshold concentration of $\mathrm{Pb}$ by at least $20 \%$. In the samples exceeding the total $\mathrm{Pb}$ concentration that would lead to the sediment being classified as hazardous on the basis of possible carcinogenic effect of $\mathrm{PbCrO}_{4}, \mathrm{~Pb}$ is actually not present mainly as $\mathrm{PbCrO}_{4}$ and no CRM hazard resulting from lead chromate can be attributed to these samples.

\subsection{4 $\mathrm{Cr}$ in $\mathrm{PbCrO}_{4}$}

For the 98 samples where $\mathrm{Cr}>161 \mathrm{mg} / \mathrm{kg}$, the slope of the linear correlation (significant at the $0.1 \%$ level) between $\mathrm{Cr}$ and $\mathrm{Pb}$ concentrations is 0.18 (Fig. 6) and the median ratio between $\mathrm{Cr}$ and $\mathrm{Pb}$ concentrations is 1.2, whereas it would theoretically be 0.25 for a sample with all $\mathrm{Cr}$ present as $\mathrm{PbCrO}_{4}$. However, thirteen samples exhibit a $\mathrm{Cr} / \mathrm{Pb}$ ratio $(0.14,0.21,0.22,0.26,0.28,0.29,0.32,0.33,0.34,0.37,0.37,0.38,0.40)$ within $50 \%$ of the theoretical value, nine of which also exceeds the threshold total $\mathrm{Cr}$ concentration by $20 \%$ or more. Some potential CRM hazard can therefore be associated with $\mathrm{Cr}$ in these 9 samples, representing $0.3 \%$ of the total number of sediments for which $\mathrm{Cr}$ data are available.

\subsection{5 $\mathrm{Pb}$ in $\mathrm{PbHAsO}_{4}$}

For the 80 samples where $\mathrm{Pb}>597 \mathrm{mg} / \mathrm{kg}$, the slope of the linear correlation ratio (significant at the $0.1 \%$ level) between $\mathrm{As}$ and $\mathrm{Pb}$ concentrations is 91 (Fig. 7) and the median ratio between $\mathrm{Pb}$ and As concentrations is 55, whereas it would be 2.8 for a sample with all $\mathrm{Pb}$ present as $\mathrm{PbHAsO}_{4}$. No sample exhibits a $\mathrm{Pb} / \mathrm{As}$ value within $50 \%$ of 2.8. A possible CRM hazard resulting from all the total $\mathrm{Pb}$ being present as $\mathrm{PbHAsO}_{4}$ can therefore be ruled out in all of the 3448 sediment samples where As and $\mathrm{Pb}$ concentrations were analysed in the same sample.

\subsection{5 $\mathrm{As}$ in $\mathrm{PbHAsO}_{4}$}

For the 3 samples where As > $216 \mathrm{mg} / \mathrm{kg}$, the ratios between As and $\mathrm{Pb}$ concentrations are 0.01, 0.02 and 4.7, whereas it would be 0.4 for a sample with all As present as $\mathrm{PbHAsO}_{4}$. No CRM hazard due to the hypothesis of As being present as $\mathrm{PbHAsO}_{4}$ should therefore be considered.

\section{Conclusions}


The objectives of this paper were twofold: firstly, to develop a methodology for applying the H7, H10 \& H11

criteria to sediments for their management if dredged and, secondly, to see what the application of the methodology can tell about sediments in the chosen data sets.

The methodology developed is applicable to results from routine sediment monitoring programs and takes into consideration the latest (known as of March 2011) development of the EU legislation related to sediment management. It relies on the data that are the most commonly available in analytical programs conducted routinely on hundreds of samples (just in France) yearly. More sophisticated techniques (e.g. X-Ray Diffraction, X-ray Absorption Spectroscopy, Extended X-ray Absorption Fine Structure) can provide detailed information on metal speciation in/on solid phases (O’Day et al. 2000, Isaure et al. 2001, Panfili et al. 2005, Peltier et al. 2005,) but they have two major shortcomings. First, they apply to minute amounts of sediments $\left(\mu \mathrm{m}^{3}\right.$ to $\mathrm{mm}^{3}$, depending on the equipment used), raising the issue of representativeness of the observations made. Second, they are not standardized or available in a sufficient number of laboratories to be used on a large number of samples. As things stand, the use of such techniques can only be promoted, not recommended, even less so prescribed.

The data bases examined contain samples that exceed the maximum trace element concentrations reported recently in the literature for sediments from different mining and smelting areas (Aleksander-Kwaterczak and Helios-Rybicka 2009). For organic micropollutants, the concentrations in this study are also extremely high, exceeding for instance the values set by the Norwegian environmental quality classification for "very bad quality" sediments (Bakke et al. 2010). It can therefore be assumed that the data examined here include "worst case" sediments as far as commonly analysed total trace elements and organic micropollutants are concerned.

Despite these worst case samples, the CRM hazard ("CRM hazard" should be understood as in the sense of the EU Waste Directive) posed by trace elements is negligible, both as regards the number of samples potentially affected (maximum observed: 9 samples out of 3,443 for $\mathrm{Cr}$ ) and as regards the real CRM hazard linked to the management of dredged sediments as wastes. Indeed, for trace elements, the dangerous inorganic substances possibly present in sediments relate to chromate, sulphide and carbonate species that are strongly bound to sediments. The corresponding CRM hazard would therefore be far lower than for readily bioavailable species, such as the pure substance in an aqueous matrix for instance. Furthermore, the evolution of metal speciation during the land disposal of sediments in oxic conditions notably involves a decrease in the sulphide and carbonate forms which are, according to the EU list of dangerous substances and the likely presence of those substances in sediments, the possible source of a CRM hazard for Cd, Co and Ni.

For organic micropollutants, the list of dangerous substances determining the hazardous character of a waste is far more extensive and includes substances of greater CRM hazard than the list of substances analysed in routine sediment monitoring networks. Now, the threshold value for the most exacting CRM category, C1, is in fact the same as that of C2 or M2 categories, which correspond to substances analysed in sediment monitoring networks. The maximum concentration in the data sets examined, even considering substances with no CRM properties and the extensive list of 168 substances analysed in the FSCMN, was $101 \mathrm{mg} / \mathrm{kg}$ for both pyrene and fluoranthene, well below the threshold value of a $\mathrm{C} 1$ substance. It therefore seems possible to disregard the CRM hazard posed by organic micropollutants in sediments, except for very specific and rare cases where sediments would receive a major input of a persistent dangerous organic substance with CRM properties of category 1. Our study does not however imply that the sediments analysed may not cause aquatic risks to species or communities living in or in contact with these sediments. The list of analytes included in the data bases does not indeed 
include a series of organic substances found in sediments and causing adverse environmental effects, synthetic compounds. However, the bioactive compounds in sediments cannot always be detected by traditional instrumental analyses (Mazurová et al. 2010) and they are not all included in the list of dangerous substances on the basis of which the hazardous character of wastes is determined. Integrated assessment of contaminated sediments is required to elucidate their ecotoxicological impact (Mazurová et al. 2010), but the implementation of legislation such as the EU Waste Directive must also rely on existing knowledge and data bases, areas in which it is hoped that the present study will prove useful.

Taking into account the $\mathrm{H} 7, \mathrm{H} 10$ and $\mathrm{H} 11$ criteria in the assessment of the possible hazard caused by sediments in the RSMNs considered will not influence the possible management options of $99.4 \%$ of these sediments if they were dredged and disposed of on land.

Other criteria need however to be considered, notably criterion H14. Indeed, biotests of sediments often indicate ecotoxicity effects (Eklund et al. 2010; Jungmann et al. 2009; Wölz et al. 2009). The problem of criterion H14 is the lack of threshold values in the legislation and the lack of standardised batteries of biotests (Kosmehl et al. 2007; Pane et al. 2008; Stevesic et al. 2007). Work is in progress to assess the H14 criterion for dredged sediments with a perspective of legislation, notably in France. The outcome of such work will enable a more thorough examination of the hazardous character of dredged sediments and lead to the identification of the most appropriate risk-based management options (Apitz 2008 a and b).

Acknowledgements The author thanks A. Morin (INERIS), C. Perard-Albin (VNF), Y. Libert (SPW, Belgium), D. de Thysebaert and J. L. Berger (DCE, Belgium), A. Huguet (IFREMER) and D. Claisse (IFREMER) for providing the data used in the present study. The help of I. Ignatiadis and S. Betelu (Brgm) in compiling the data on aqueous solubility was greatly appreciated. We would like to extend particular thanks, both professional and personal, to D. Darmendrail (BRGM), who proved most helpful in providing a clear, up-to-date view of the EU legislation and regulations on waste and sediment management.

\section{References}

AFNOR (1996) Soil quality, Soils, Sediments. Total solubilizing by acid attack. Norm NF X 31-147, 12 pp

AFNOR (2000) Characterisation of sludges - Determination of polynuclear aromatic hydrocarbons (PAH) and polychlorinated biphenyls (PCB). Norm XP X 33-012, 28 pp

Akcay H, Oguz A, Karapire C (2003) Study of heavy metal pollution and speciation in Buyak Menderes and Gediz river sediments. Water Res 37:813-822

Aleksander-Kwaterczak U, Helios-Rybicka U (2009) Contaminated sediments as a potential source of $\mathrm{Zn}, \mathrm{Pb}$, and $\mathrm{Cd}$ for a river system in the historical metalliferous ore mining and smelting industry area of South Poland. J Soils Sediments 9:13-22

Apitz SE (2008 a) Adaptive management principles and sediment management. A call for discussions J Soils Sediments 8:359-362

Apitz SE (2008 b) Is risk-based, sustainable sediment management consistent with European policy? J Soils Sediments 8:461-466 
Assemblée Nationale (2008) Projet de loi de programme relatif à la mise en œuvre du Grenelle de l'environnement. http://www.assemblee-nationale.fr/13/ta/ta0200.asp Accessed November 30, 2009

Bakke T, Källqvist T, Ruus A, Breedveld G D, Hylland K (2010) Development of sediment quality criteria in Norway. J Soils Sediments 10:172-178

Barnhart J (1997) Occurrences, Uses, and Properties of Chromium. Regul Toxicol Pharm 26:S3-S7

Baruah NK, Kotoky P, Bhattacharyya KG, Borah GC (1996) Metal speciation in Jhanji River sediments. Sci Total Environ 193:1-12

Bettinelli M, Beone G M, Spezia S, Baffi C (2000) Determination of heavy metals in soils and sediments by microwave-assisted digestion and inductively coupled plasma optical emission spectrometry analysis. Anal Chim Acta 424(2):289-296

Blute NK, Jay JA, Swartz CH, Brabander DJ, Hemond HF (2009) Aqueous and solid phase arsenic speciation in the sediments of a contaminated wetland and riverbed. Appl Geochem 24:346-358

Caudill SP, Wong LY, Turner WE, Lee R, Henderson A, Patterson DG Jr (2007) Percentile estimation using variable censored data. Chemosphere 68:169-180

Chapman PM, Wang FY, Janssen C, Persoone G, Allen HE (1998) Ecotoxicology of metals in aquatic sediments: binding and release, bioavailability, risk assessment, and remediation. Can J Fish Aquat Sci $55: 2221-2243$

Cornelis C, Bierkens J, Joris I, Nielsen P, Pensaert S (2006) Quality criteria for re-use of organotin-containing sediments on land. J Soils Sediments 6:156-162

Di Toro DM, Mahony JD, Hansen DJ, Scott KJ, Carlson AR, Ankley GT (1992) Acid-volatile sulfide predicts the acute toxicity of cadmium and nickel in sediments. Enviro Sci Technol 26:96-101

Du Laing G, Vanthuyne DRJ, Vandecasteele B, Tack FMG, Verloo MG (2007) Influence of hydrological regime on pore water metal concentrations in a contaminated sediment-derived soil. Environ Pollut 147:615625

Eklund B, Elfström M, Gallego I, Bengtsson B-E, Breitholtz M (2010) Biological and chemical characterization of harbour sediments from the Stockholm area. J Soils Sediments 10:127-141

EPA (1995 a) SW-846 EPA Method 3050B, Acid digestion of sediments, sludges and soils, in: Test Methods for Evaluating Solid Waste, 3rd Edition, 3rd Update, US Environmental Protection Agency, Washington DC

EPA (1995 b) SW-846 EPA Method 3051, Microwave assisted acid digestion of sediments, sludges, soils and oils, in: Test Methods for Evaluating Solid Waste, 3rd Edition, 3rd Update, US Environmental Protection Agency, Washington DC

EPA (1995 c) SW-846 EPA Method 3052, Microwave assisted acid digestion of siliceous and organically based matrices, in: Test Methods for Evaluating Solid Waste, 3rd Edition, 3rd Update, US Environmental Protection Agency, Washington, DC

European Commission (2000) List of wastes pursuant to Article 1(4) of Council Directive 91/689/EEC on hazardous waste. Official Journal of the European Communities, 6.9.2000, L 226/3 - 226/24. http://eurlex.europa.eu/LexUriServ/LexUriServ.do?uri=OJ:L:2000:226:0003:0024:EN:PDF Accessed Feb. 25, 2010

Page 14 sur 27 
European Commission (2006) Directive 2006/118/ec of the European Parliament and of the Council of 12 December 2006 on the protection of groundwater against pollution and deterioration. Official Journal of the European Union 27/12/2006, L $372 / 19 \quad-\quad 31$. $\underline{\text { http://eur- }}$ lex.europa.eu/LexUriServ/LexUriServ.do?uri=OJ:L:2006:372:0019:0031:EN:PDF Accessed February 27,2010

European Commission (2008a) Directive 2008/98/EC of the European Parliament and of the Council of 19 November 2008 on waste and repealing certain Directives. Official Journal of the European Union L 312/3-30, 22/11/2008, $\quad$ http://eurlex.europa.eu/LexUriServ/LexUriServ.do?uri=OJ:L:2008:312:0003:0030:EN:PDF Accessed November 31,2009

European Commission (2008b) Follow-up to 5th Meeting of the Competent Authorities for the Implementation of Regulation (EC) 1907/2006 (REACH). 25-26 September 2008. Doc: CA/24/2008 rev.2. http://ec.europa.eu/environment/chemicals/reach/pdf/waste_paper_ca_081026_en.pdf. Accessed March 17,2011

European Commission (2008c) Regulation (EC) $n^{\circ} 1272 / 2008$ of the European Parliament and of the Council of 16 December 2008 on classification, labelling and packaging of substances and mixtures, amending and repealing Directives 67/548/EEC and 1999/45/EC, and amending Regulation (EC) $\mathrm{n}^{\circ}$ 1907/2006. http://eur-lex.europa.eu/LexUriServ/LexUriServ.do?uri=OJ:L:2008:353:0001:1355:EN:PDF Accessed March 17, 2011

European Commission (2009 a) Commission Directive 2009/90/EC of 31 July 2009 laying down, pursuant to Directive 2000/60/EC of the European Parliament and of the Council, technical specifications for chemical analysis and monitoring of water status. Official Journal of the European Union, 1 August 2009, L201-36-38. http://eurlex.europa.eu/LexUriServ/LexUriServ.do?uri=OJ:L:2009:201:0036:0038:EN:PDF Accessed February 27,2010

European Commission (2009 b) Commission Directive 2009/2/EC of 15 January 2009 amending, for the purpose of its adaptation to technical progress, for the 31st time, Council Directive 67/548/EEC on the approximation of the laws, regulations and administrative provisions relating to the classification, packaging and labelling of dangerous substances, Official Journal of the European Union L 11/6-82, 16/1/2009, http://eur-lex.europa.eu/LexUriServ/LexUriServ.do?uri=OJ:L:2009:011:0006:0082:EN:PDF Accessed February 27, 2010

Farnham IM, Singh AK, Stetzenbach KJ, Johannesson KH (2002) Treatment of nondetects in multivariate analysis of groundwater geochemistry data. Chemometr Intell Lab 60:265-281

Fytianos K, Lourantou A (2004) Speciation of elements in sediment samples collected at lakes Volvi and Koronia, N. Greece. Environ Int 30:11-17

Galvez-Cloutier R, Dube JS (1998) An evaluation of fresh water sediments contamination: The Lachine Canal sediments case, Montreal, Canada. Part II: Heavy metal particulate speciation study. Water Air Soil Poll 102:281-302

Gooding MP, Newton TJ, Bartsch MR, Hornbuckle KC (2006) Toxicity of synthetic musks to early life stages of the freshwater mussel Lampsilis cardium. Arch Environ Contam Toxicol 51:549-558

Page 15 sur 27 
Graham AM, Wadhawan AR, Bouwer EJ (2009) Chromium occurrence and speciation in Baltimore harbour sediments and porewater, Baltimore, Maryland, USA. Environ Toxicol Chem 28:471-480

Helsel DR, Hirsch RM (1991). Statistical Methods in Water Resources. U.S. Geological Survey, Techniques of Water-Resources Investigations Book 4, Chapter A3, Chapter 13. http://pubs.usgs.gov/twri/twri4a3/pdf/chapter13.pdf Accessed February 27, 2010

Holvoet K, Seuntjens P, Mannaerts R, De Schepper V, Vanrolleghem PA (2007) The dynamic water-sediment system: results from an intensive pesticide monitoring campaign. Water Sci Technol 55:177-182

INERIS (2006) Nickel et ses dérivés. www.ineris.fr/print.php?module=doc\&action=getFile\&id=183 Accessed December 5, 2009

INERIS (2009) Nickel et ses oxides. http://www.inrs.fr/INRS-PUB/inrs01.nsf/IntranetObjectaccesParReference/FT\%2068/\$File/ft68.pdf Accessed December 5, 2009

INRS (2009) Nickel et ses oxydes. Fiche toxicologique FT 68, 12 pp. http://www.inrs.fr/INRSPUB/inrs01.nsf/IntranetObject-accesParReference/FT\%2068/\$File/ft68.pdf Accessed February 22, 2010

Isaure MP, Laboudigue A, Manceau A, Sarret G, Tiffreau C, Trocellier P (2001) Characterisation of zinc in slags originated from a contaminated sediment by coupling $\mu$-PIXE, $\mu$-RBS, $\mu$-EXAFS and powder EXAFS spectroscopy. Nucl Instrum Meth B 181:598-602

ISO (2004) ISO 15586 Water quality. Determination of trace elements using atomic absorption spectrometry with graphite furnace. $23 \mathrm{pp}$

ISO (2009) ISO 11885 Water quality. Determination of selected elements by inductively coupled plasma optical emission spectrometry (ICP-OES). 36 pp

Jay JA, Blute NK, Lin K, Senn D, Hemond HF, Durant JL (2005) Controls on arsenic speciation and solid-phase partitioning in the sediments of a two-basin lake. Environ Sci Technol 39:9174-9181

Jungmann D, Bandow C, Gildemeister T, Nagel R, Preuss TG, Ratte H T, Shinn C, Weltje L, Maes H M (2009) Chronic toxicity of fenoxycarb to the midge Chironomus riparius after exposure in sediments of different composition. J Soils Sediments 9:94-102

Kosmehl T, Krebs F, Manz W, Braunbeck T, Hollert H (2007) Differentiation between bioavailable and total hazard potential of sediment-induced DNA fragmentation as measured by the comet assay with zebrafish embryos. J Soils Sediments 7:377-387

Lam MHW, Tjia AYW, Chan CC, Chan W P, Lee WS (1997) Speciation study of chromium, copper and nickel in coastal estuarine sediments polluted by domestic and industrial effluents. Mar Pollut Bull 34:949959

Le Grenelle, 2007 http://www.legrenelle-environnement.fr/spip.php Accessed November 30, 2009

Lespagnol G (2003) Lixiviation du Chrome, du Cuivre et de l'Arsenic (CCA) à partir de sols contaminés sur des sites de traitement du bois. Thèse $\mathrm{n}^{\circ} 318$ CD de 1'Ecole Nationale Supérieure des Mines de SaintEtienne. 182 pp. + annexes

Lide DR (2005) CRC Handbook of Chemistry and Physics, 86th edition, 2660 pp., CRC Press, Boca Raton, FL

Liu M, Cheng S, Ou D, Yang Y, Liu H, Hou L, Gao L, Xu S (2008) Organochlorine pesticides in surface sediments and suspended particulate matters from the Yangtze estuary, China. Environ Pollut 156:168173

Page 16 sur 27 
Loska K, Wiechula D (2002) Speciation of cadmium in the bottom sediment of Rybnik Reservoir. Water Air Soil Poll 141:73-89

Malik A, Ojha P, Singh KP (2009) Levels and distribution of persistent organochlorine pesticide residues in water and sediments of Gomti River (India) - a tributary of the Ganges River. Environ Monit Assess 148:421-435

Martin N, Schuster I, Peiffer S (1996) Two experimental methods to determine the speciation of cadmium in sediment from the River Neckar. Acta hydrochimica et hydrobiologica 24:68-76

Martinez CE, Jacobson AR, McBride MB (2004) Lead phosphate minerals: Solubility and dissolution by model and natural ligands. Env Sci Technol 38:5584-5590

Mazurová E, Hilscherová K, Š́́dlová-Štěpánková T, Köhler HR, Triebskorn R, Jungmann D, Giesy JP, Bláha L (2010) Chronic toxicity of contaminated sediments on reproduction and histopathology of the crustacean Gammarus fossarum and relationship with the chemical contamination and in vitro effects. J Soils Sediments 10:423-433

Ministère Québécois du Développement durable de l'Environnement et des Parcs, 2009 http://www.mddep.gouv.qc.ca/eau/bassinversant/bassins/boyer/statdescripteau-boyer.htm Accessed February 27, 2010

Mortimer RJG, Rae JE (2000) Metal speciation $(\mathrm{Cu}, \mathrm{Zn}, \mathrm{Pb}, \mathrm{Cd})$ and organic matter in oxic to suboxic salt marsh sediments, Severn Estuary, southwest Britain. Mar Pollut Bull 40:377-386

O'Day PA, Carroll SA, Randall S, Martinelli RE, Anderson SL, Jelinski J, Knezovich JP (2000) Metal speciation and bioavailability in contaminated estuary sediments, Alameda Naval Air Station, California. Environ Sci Technol 34:3665-3673

Pane L, Giacco E, Corrà C, Greco G, Mariottini GL, Varisco F, Faimali M (2008) Ecotoxicological evaluation of harbour sediments using marine organisms from different trophic levels. J Soils Sediments 8:74-79

Panfili F, Manceau A, Sarret G, Spadini L, Kirpichtchikova T, Bert V, Laboudigue A, Marcus M, Ahamdach N, Libert M (2005) The effect of phytostabilization on $\mathrm{Zn}$ speciation in a dredged contaminated sediment using scanning electron microscopy, X-ray fluorescence, EXAFS spectroscopy and principal component analysis. Geochim Cosmochim Acta 9:2265-5584

Pardo R, Barrado E, Perez L, Vega M (1990) Determination and speciation of heavy metals in sediments of the Pisuerga River. Wat Res 24:373-379

Peck AM, Linebaugh EK, Hornbuckle, KC (2006) Synthetic musk fragrances in Lake Erie and Lake Ontario sediment cores. Env Sci Technol 40:5629-5635

Peltier E, Dahl AL, Gaillard JF (2005) Metal speciation in anoxic sediments: When sulfides can be construed as oxides. Environ Sci Technol 39:311-316

Petersen W, Willer E, Willamowski C (1997) Remobilization of trace elements from polluted anoxic sediments after resuspension in oxic water. Water Air Soil Poll 99:515-522

Reboreda R, Cacador I (2007) Copper, zinc and lead speciation in salt marsh sediments colonised by Halimione portulacoides and Spartina maritime. Chemosphere 69:1655-1661

Savonina EY, Fedotov PS, Wennrich R (2006) Five-step dynamic fractionation of copper, zinc, and lead species in soils, silts, and bottom sediments using rotating coiled columns. J Anal Chem 61:702-708

Page 17 sur 27 
Stesevic D, Feiler U, Sundic D, Mijovic S, Erdinger L, Seiler T-B, Heininger P, Hollert H (2007) Application of a new sediment contact test with Myriophyllum aquaticum and of the aquatic lemna test to assess the sediment quality of Lake Skadar. J Soils Sediments 7:342-349

Tessier A, Campbell P G C., Bisson M (1979) Sequential extraction procedure for the speciation of particulate trace-metals. Anal Chem 51:844-851

Tokalioglu S, Kartal S, Elci L (2000) Determination of heavy metals and their speciation in lake sediments by flame atomic absorption spectrometry after a four-stage sequential extraction procedure. Anal Chimica Acta 413:33-40

Torres RJ, Abessa DMS, Santos FC, Maranho LA, Davanso MB, do Nascimento MRL, Mozeto AA (2009). Effects of dredging operations on sediment quality: contaminant mobilization in dredged sediments from the Port of Santos, SP, Brazil. J Soils Sediments 9:420-432

Villaverde J, Hildebrandt A, Martinez E, Lacorte S, Morillo E, Maqueda C, Viana P, Barceló D (2008) Priority pesticides and their degradation products in river sediments from Portugal. Sci Total Environ 390:507513

Wikipedia (2009) Arsenic acid. http://en.wikipedia.org/wiki/Arsenic_acid Accessed December 5, 2009

Wölz J, Borck D, Witt G, Hollert H (2009) Ecotoxicological characterization of sediment cores from the western Baltic Sea (Mecklenburg Bight) using GC-MS and in vitro biotests. J Soils Sediments 9:400-410

Yuan CG, Shi JB, He B, Liu JF, Liang L, Jiang GB (2004) Speciation of heavy metals in marine sediments from the East China Sea by ICP-MS with sequential extraction. Environ Int 30:769-783

Zayed AM, Terry N (2003) Chromium in the environment: factors affecting biological remediation. Plant Soil 249:139-156 
Table 1 Aqueous solubility of the dangerous inorganic substances including the trace elements most commonly analysed in routine sediment monitoring programs

\begin{tabular}{|c|c|c|c|c|c|c|c|}
\hline $\begin{array}{c}\text { Trace } \\
\text { element }\end{array}$ & $\begin{array}{c}\text { CRM } \\
\text { Substance } \\
\end{array}$ & $\begin{array}{c}\text { Solubility } \\
\left(\mathrm{g} / 100 \mathrm{~g} \mathrm{H}_{2} \mathrm{O}\right)\end{array}$ & $\operatorname{Ref}$. & $\begin{array}{c}\text { Trace } \\
\text { element }\end{array}$ & CRM Substance & $\begin{array}{c}\text { Solubility } \\
\left(\mathrm{g} / 100 \mathrm{~g} \mathrm{H}_{2} \mathrm{O}\right)\end{array}$ & $\operatorname{Ref}$. \\
\hline \multirow[t]{6}{*}{ As } & $\mathrm{PbHAsO}_{4}$ & insoluble & 1 & \multirow[t]{12}{*}{$\mathrm{Ni}$} & $\mathrm{NiCO}_{3}$ & $0.0043\left(20^{\circ} \mathrm{C}\right)$ & 1 \\
\hline & $\mathrm{As}_{2} \mathrm{O}_{5}$ & $65.82\left(20^{\circ} \mathrm{C}\right)$ & 1 & & $\mathrm{NiSO}_{4}$ & $40.4\left(25^{\circ} \mathrm{C}\right)$ & 1 \\
\hline & $\mathrm{As}_{2} \mathrm{O}_{3}$ & $2.05\left(25^{\circ} \mathrm{C}\right)$ & 1 & & $\mathrm{NiCl}_{2}$ & $67.5\left(25^{\circ} \mathrm{C}\right)$ & 1 \\
\hline & $\left(\mathrm{C}_{2} \mathrm{H}_{5} \mathrm{O}\right)_{3} \mathrm{AsO}$ & n. a. & & & $\mathrm{Ni}(\mathrm{OH})_{2}$ & $0.00015\left(20^{\circ} \mathrm{C}\right)$ & 1 \\
\hline & $\mathrm{H}_{3} \mathrm{AsO}_{4}$ & 16.7 & 2 & & $\mathrm{Ni}\left(\mathrm{NO}_{3}\right)_{2}$ & $99\left(25^{\circ} \mathrm{C}\right)$ & 3 \\
\hline & & & & & $\mathrm{NiO}$ & insoluble & 1 \\
\hline \multirow[t]{8}{*}{ Cd } & $\mathrm{CdCl}_{2}$ & $120\left(25^{\circ} \mathrm{C}\right)$ & 1 & & $\mathrm{Ni}(\mathrm{O})_{2}$ & decomposes & 4 \\
\hline & $\mathrm{CdCl}_{2} .5 / 2 \mathrm{H}_{2} \mathrm{O}$ & $121\left(25^{\circ} \mathrm{C}\right)$ & 1 & & $\mathrm{Ni}_{2} \mathrm{O}_{3}$ & insoluble & 1 \\
\hline & $\mathrm{CdF}_{2}$ & $4.36\left(25^{\circ} \mathrm{C}\right)$ & 1 & & $\mathrm{NiS}$ & insoluble & 1 \\
\hline & $\mathrm{CdSO}_{4}$ & $76.7\left(25^{\circ} \mathrm{C}\right)$ & 1 & & $\mathrm{Ni}_{3} \mathrm{~S}_{2}$ & n. a. & \\
\hline & $\mathrm{CdSO}_{4} \cdot 8 \mathrm{H}_{2} \mathrm{O}$ & $76.7\left(25^{\circ} \mathrm{C}\right)$ & 1 & & $\mathrm{Ni}(\mathrm{CO})_{4}$ & n. a. & \\
\hline & $\mathrm{CdS}$ & insoluble & 1 & & & & \\
\hline & $\mathrm{CdO}$ & insoluble & 1 & \multirow[t]{7}{*}{$\mathbf{P b}$} & $\mathrm{PbHAsO}_{4}$ & insoluble & 1 \\
\hline & & & & & $\mathrm{PbCrO}_{4}$ & $0.0000172\left(20^{\circ} \mathrm{C}\right)$ & 1 \\
\hline \multirow[t]{6}{*}{ Co } & $\mathrm{CoCO}_{3}$ & $0.00014\left(20^{\circ} \mathrm{C}\right)$ & 1 & & $\mathrm{~Pb}\left(\mathrm{~N}_{3}\right)_{2}$ & $0.023\left(18^{\circ} \mathrm{C}\right)$ & 1 \\
\hline & $\mathrm{CoCl}_{2}$ & $56.2\left(25^{\circ} \mathrm{C}\right)$ & 1 & & $\mathrm{~Pb}\left(\mathrm{CH}_{3} \mathrm{COO}\right)_{2}$ & $44.3\left(20^{\circ} \mathrm{C}\right)$ & 1 \\
\hline & $\mathrm{Co}\left(\mathrm{NO}_{3}\right)_{2}$ & $103\left(25^{\circ} \mathrm{C}\right)$ & 1 & & $\mathrm{~Pb}\left(\mathrm{C}_{2} \mathrm{H}_{3} \mathrm{O}_{2}\right)_{2} 3 \mathrm{H}_{2} \mathrm{O}$ & very soluble & 1 \\
\hline & $\mathrm{CoSO}_{4}$ & $38.3\left(25^{\circ} \mathrm{C}\right)$ & 1 & & $\mathrm{~F}_{6} \mathrm{PbSi}$ & n. a. & \\
\hline & $\mathrm{Co}\left(\mathrm{CH}_{3} \mathrm{COO}\right)_{2}$ & very soluble & 1 & & $\mathrm{~Pb}_{3}(\mathrm{PO} 4)_{2}$ & insoluble & 1 \\
\hline & & & & Zn & $\mathrm{ZnCrO}_{4}$ & 3.08 & 1 \\
\hline \multirow[t]{6}{*}{$\mathrm{Cr}$} & $\mathrm{CrO}_{3}$ & $169\left(25^{\circ} \mathrm{C}\right)$ & 1 & \multirow[t]{6}{*}{$\mathrm{Cr}$} & $\mathrm{K}_{2} \mathrm{CrO}_{4}$ & 65.025 & 1 \\
\hline & $\mathrm{CaCrO}_{4} 2 \mathrm{H}_{2} \mathrm{O}$ & $13.22\left(20^{\circ} \mathrm{C}\right)$ & 1 & & $\mathrm{~K}_{2} \mathrm{Cr}_{2} \mathrm{O}_{7}$ & $15.1\left(25^{\circ} \mathrm{C}\right)$ & 1 \\
\hline & $\mathrm{Cr}_{2}\left(\mathrm{CrO}_{4}\right)_{3}$ & n. a. & & & $\mathrm{Na}_{2} \mathrm{CrO}_{4}$ & $87.65\left(25^{\circ} \mathrm{C}\right)$ & 1 \\
\hline & $\mathrm{CrO}_{2} \mathrm{Cl}_{2}$ & n. a. & & & $\mathrm{SrCrO}_{4}$ & very soluble & 1 \\
\hline & $\mathrm{PbCrO}_{4}$ & $0.0000172\left(20^{\circ} \mathrm{C}\right)$ & 1 & & $\mathrm{ZnCrO}_{4}$ & 3.08 & 1 \\
\hline & & & & & $\left(\mathrm{NH}_{4}\right)_{2} \mathrm{Cr}_{2} \mathrm{O}_{7}$ & $37\left(25^{\circ} \mathrm{C}\right)$ & 1 \\
\hline
\end{tabular}

ref 1: Lide 2005

2: Wikipedia 2009

3: INERIS 2006

4: INERIS 2009 
Table 2 Inorganic CRM substances considered possibly present in sediments and including one (or two) trace element(s) analysed in routine sediment monitoring programs, and threshold concentration (total trace element concentration) that would lead to a classification as "hazardous waste" of a sediment in which the trace element would be present solely as the substance considered. The substances in bold type are the most stringent ones, considered in the rest of the data analysis

\begin{tabular}{|c|c|c|}
\hline $\begin{array}{l}\text { Trace } \\
\text { element }\end{array}$ & $\begin{array}{l}\text { CRM substance(s) } \\
\text { (CRM ranking) }\end{array}$ & $\begin{array}{c}\text { Threshold concentration of } \\
\text { trace element } \\
(\mathrm{mg} / \mathrm{kg} \text { dry weight },<2 \mathrm{~mm})\end{array}$ \\
\hline$\overline{\text { As }}$ & $\mathrm{PbHAsO}_{4}(\mathrm{C} 1 \mathrm{R} 1 \mathrm{R} 3)$ & 216 \\
\hline Cd & $\begin{array}{l}\text { CdS (C2 M3 R3) } \\
\text { CdO (C2 M3 R3) }\end{array}$ & $\begin{array}{l}778 \\
875\end{array}$ \\
\hline Co & $\mathrm{CoCO}_{3}(\mathrm{C} 2 \mathrm{M} 3 \mathrm{R} 2)$ & 495 \\
\hline $\mathrm{Cr}$ & $\begin{array}{c}\mathrm{PbCrO}_{4}(\mathrm{C} 2 \mathrm{R} 1 \mathrm{R} 3) \\
\mathrm{ZnCrO}_{4}(\mathrm{C} 1)\end{array}$ & $\begin{array}{l}161 \\
287\end{array}$ \\
\hline $\mathbf{N i}$ & $\begin{array}{c}\mathrm{NiCO}_{3}(\mathrm{C} 1 \mathrm{M} 3 \mathrm{R} 2) \\
\mathrm{NiS}(\mathrm{C} 1) \\
\mathrm{NiO}(\mathrm{C} 1) \\
\mathrm{Ni}(\mathrm{OH})_{2}(\mathrm{C} 3)\end{array}$ & $\begin{array}{c}494 \\
647 \\
787 \\
6330\end{array}$ \\
\hline $\mathbf{P b}$ & $\begin{array}{c}\mathrm{PbHAsO}_{4}(\mathrm{C} 1 \mathrm{R} 1 \mathrm{R} 3) \\
\mathrm{PbCrO}_{4}(\mathrm{C} 2 \mathrm{R} 1 \mathrm{R} 3) \\
\mathrm{Pb}_{3}\left(\mathrm{PO}_{4}\right)_{2}(\mathrm{R} 1 \mathrm{R} 3)\end{array}$ & $\begin{array}{c}\mathbf{5 9 7} \\
641 \\
3831\end{array}$ \\
\hline $\mathbf{Z n}$ & $\mathrm{ZnCrO}_{4}(\mathrm{C} 1)$ & 361 \\
\hline
\end{tabular}


Table 3 Descriptive statistics of the CRM organic substances quantified in at least $0.5 \%$ of the data set from the 2007 campaign of the French Surveillance Control Monitoring Network of sediments

\begin{tabular}{lcccccc}
\hline \multicolumn{1}{c}{ SUBSTANCE } & $\begin{array}{c}\text { Number of } \\
\text { samples }\end{array}$ & $\begin{array}{c}>\mathbf{Q} \text { L } \\
\%\end{array}$ & $\begin{array}{c}\text { Max } \\
(\mathrm{mg} / \mathrm{kg})\end{array}$ & $\begin{array}{c}\text { Median } \\
(\mathrm{mg} / \mathrm{kg})\end{array}$ & $\begin{array}{c}\text { CRM } \\
\text { category }\end{array}$ & $\begin{array}{c}\text { Threshold conc. } \\
(\mathrm{mg} / \mathrm{kg})\end{array}$ \\
\hline Benzo(a)anthracene & 1323 & 76.1 & 58 & 0.003 & $\mathrm{C} 2$ & $\geq 1000$ \\
Chrysene & 1323 & 67.3 & 49 & 0.078 & $\mathrm{C} 2 \mathrm{M} 3$ & $\geq 1000$ \\
Benzo(a)pyrene & 1627 & 64.0 & 62 & 0.005 & $\mathrm{C} 2 \mathrm{M} 2$ & $\geq 1000$ \\
Benzo(k)fluoranthene & 1630 & 63.4 & 27 & 0.022 & $\mathrm{C} 2$ & $\geq 1000$ \\
Ethyl hexyl phthalate & 1526 & 49.5 & 18 & 0.050 & $\mathrm{R} 2$ & $\geq 5000$ \\
Dibenzo(ah)anthracene & 1353 & 42.1 & 15 & 0.010 & $\mathrm{C} 2$ & $\geq 1000$ \\
Toluene & 559 & 38.2 & 1.5 & 0.010 & $\mathrm{R} 3$ & $\geq 50000$ \\
Naphtalene & 1630 & 21.1 & 9 & 0.010 & $\mathrm{C} 3$ & $\geq 10000$ \\
Diuron & 924 & 4.9 & 0.070 & 0.001 & $\mathrm{C} 3$ & $\geq 10000$ \\
Nonylphenols & 1362 & 2.7 & 53 & 0.010 & $\mathrm{R} 3$ & $\geq 50000$ \\
Isoproturon & 924 & 1.6 & 0.025 & 0.001 & $\mathrm{C} 3$ & $\geq 10000$ \\
Trichloroethylene & 380 & 0.8 & 0.014 & 0.003 & $\mathrm{C} 2 \mathrm{M} 3$ & $\geq 1000$ \\
Tetrachloroethene & 778 & 0.8 & 0.013 & 0.001 & $\mathrm{C} 3$ & $\geq 10000$ \\
Chloroform & 778 & 0.5 & 0.010 & 0.001 & $\mathrm{C} 3$ & $\geq 10000$ \\
Dichloromethane & 778 & 0.5 & 0.133 & 0.001 & $\mathrm{C} 3$ & $\geq 10000$ \\
& & & & & &
\end{tabular}

Q L: quantification limit 
Table 4 Descriptive statistics of the CRM organic substances analysed in the inland waterways of Northern, Central and Eastern France, and Wallony. Data from the Walloon non-navigable waterways are presented in italics

\begin{tabular}{|c|c|c|c|c|c|}
\hline SUBSTANCE & $\begin{array}{c}\text { Number of } \\
\text { samples } \\
\end{array}$ & $\begin{array}{c}\text { Max } \\
(\mathrm{mg} / \mathrm{kg}) \\
\end{array}$ & $\begin{array}{l}\text { Median } \\
(\mathrm{mg} / \mathrm{kg}) \\
\end{array}$ & $\begin{array}{c}\text { CRM } \\
\text { category } \\
\end{array}$ & $\begin{array}{c}\text { Threshold conc. } \\
(\mathrm{mg} / \mathrm{kg})\end{array}$ \\
\hline Benzo(a)anthracene & 1128 & 30.3 & 0.4 & $\mathrm{C} 2$ & $\geq 1000$ \\
\hline Benzo(a)pyrene & 1145 & 29.1 & 0.5 & $\mathrm{C} 2 \mathrm{M} 2$ & $\geq 1000$ \\
\hline Benzo(k)fluoranthene & 1144 & 12.5 & 0.1 & $\mathrm{C} 2$ & $\geq 1000$ \\
\hline Chrysene & 1128 & 35.9 & 0.6 & C2 M3 & $\geq 1000$ \\
\hline Dibenzo(ah)anthracene & 1128 & 9.7 & 0.1 & $\mathrm{C} 2$ & $\geq 1000$ \\
\hline Naphtalene & 1128 & 21.3 & 0.1 & $\mathrm{C} 3$ & $\geq 10000$ \\
\hline$\Sigma 16 P A H(E P A$ list $)$ & 191 & 145 & 4.4 & $C 2$ & $\geq 1000$ \\
\hline Benzene & 568 & 0.4 & 0.001 & C1 M2 & $\geq 1000$ \\
\hline Toluene & 568 & 18.5 & 0.001 & R3 & $\geq 50000$ \\
\hline$\Sigma B T E X$ & 238 & 15.7 & 0.9 & C1 M2 & $\geq 1000$ \\
\hline Hexachlorobenzene & 39 & 0.37 & 0.01 & $\mathrm{C} 2$ & $\geq 1000$ \\
\hline$\alpha-\mathrm{HCH}$ & 30 & 0.04 & 0.01 & $\mathrm{C} 3$ & $\geq 10000$ \\
\hline pp'-DDT & 31 & 0.05 & 0.01 & $\mathrm{C} 3$ & $\geq 10000$ \\
\hline$\sum$ chlorinated pesticides & 238 & $<0.01$ & $<0.01$ & $C 2$ & $\geq 1000$ \\
\hline
\end{tabular}


Table 5 Descriptive statistics for the CRM organic substances analysed in the French marine sediments routine monitoring networks

\begin{tabular}{lccccc}
\hline \multicolumn{1}{c}{ SUBSTANCE } & $\begin{array}{c}\text { Number of } \\
\text { samples }\end{array}$ & $\begin{array}{c}\text { Max. } \\
(\mathrm{mg} / \mathrm{kg})\end{array}$ & $\begin{array}{c}\text { Median } \\
(\mathrm{mg} / \mathrm{kg})\end{array}$ & $\begin{array}{c}\text { CRM } \\
\text { category }\end{array}$ & $\begin{array}{c}\text { Threshold conc. } \\
(\mathrm{mg} / \mathrm{kg})\end{array}$ \\
\hline Benzo(a)anthracene & 702 & 19.5 & 0.05 & $\mathrm{C} 2$ & $\geq 1000$ \\
Benzo(a)pyrene & 952 & 22.4 & 0.05 & $\mathrm{C} 2 \mathrm{M} 2$ & $\geq 1000$ \\
Benzo(k)fluoranthene & 879 & 10.6 & 0.04 & $\mathrm{C} 2$ & $\geq 1000$ \\
Dibenzo(ah)anthracene & 448 & 0.6 & 0.003 & $\mathrm{C} 2$ & $\geq 1000$ \\
Chrysene & 695 & 26.7 & 0.05 & $\mathrm{C} 2 \mathrm{M} 3$ & $\geq 1000$ \\
Naphtalene & 656 & 5.0 & 0.02 & $\mathrm{C} 3$ & $\geq 10000$ \\
pp'-DDT & 479 & 0.36 & 0.0001 & $\mathrm{C} 3$ & $\geq 10000$ \\
a-HCH & 479 & 0.012 & 0.00005 & $\mathrm{C} 3$ & $\geq 10000$ \\
\hline
\end{tabular}


Table 6 Descriptive statistics for the trace elements total concentrations of the data set from the French marine sediments monitoring networks

\begin{tabular}{ccrrcc}
\hline $\begin{array}{c}\text { Trace } \\
\text { element }\end{array}$ & $\begin{array}{c}\text { Number of } \\
\text { samples }\end{array}$ & $\begin{array}{c}\text { Max. } \\
(\mathrm{mg} / \mathrm{kg})\end{array}$ & $\begin{array}{c}\text { Median } \\
(\mathrm{mg} / \mathrm{kg})\end{array}$ & $\begin{array}{c}\text { Threshold } \\
\text { conc. }(\mathrm{mg} / \mathrm{kg})\end{array}$ & $\begin{array}{c}\text { Substance considered } \\
\mathrm{CRM} \text { category }\end{array}$ \\
\hline $\mathbf{A s}$ & 800 & 69 & 13 & $\geq 216$ & PbHAsO $_{4} ; \mathrm{C} 1$ \\
$\mathbf{C d}$ & 1362 & 8.6 & 0.2 & $\geq 778$ & $\mathbf{C d S} \mathrm{C} 2$ \\
$\mathbf{C r}$ & 1203 & 636 & 45 & $\geq 161$ & PbCrO $_{4} ; \mathrm{C} 1$ \\
$\mathbf{N i}$ & 1192 & 237 & 18 & $\geq 494$ & $\mathbf{N i C O}_{3} ; \mathrm{C} 1$ \\
$\mathbf{P b}$ & 1361 & 662 & 33 & $\geq 597$ & PbHAsO $_{4} ; \mathrm{C} 1$ \\
$\mathbf{Z n}$ & 1360 & 2800 & 105 & $\geq 361$ & $\mathbf{Z n C r O}_{4} ; \mathrm{C} 1$ \\
\hline
\end{tabular}


Table 7 Examples of analytical uncertainty in trace metal determinations in sediments or sewage soil amended soil

\begin{tabular}{|c|c|c|c|c|}
\hline \multirow[b]{2}{*}{ Ref. and matrix / Parameter } & \multicolumn{4}{|c|}{ Trace element } \\
\hline & As & $\mathrm{Cr}$ & $\mathbf{P b}$ & Zn \\
\hline \multicolumn{5}{|l|}{ ISO 15586; sediment } \\
\hline Concentration $(\mathrm{mg} / \mathrm{kg})$ & 16.3 & 51 & n. a. & n. a. \\
\hline Reproducibility (C. V.,\%) & 26.2 & 21.7 & - & - \\
\hline \multicolumn{5}{|c|}{ Bettinelli et al. 2000; CRM 277 estuarine sediment } \\
\hline Concentration (mg/kg) & n. a. & 192 & 146 & 547 \\
\hline Reproducibility (C. V.,\%) & - & 12 & 22 & 14 \\
\hline \multicolumn{5}{|c|}{ Bettinelli et al. 2000; CRM 143 sewage sludge amended soil } \\
\hline Concentration (mg/kg) & n. a. & 188 & 1173 & 1155 \\
\hline Reproducibility (C. V.,\%) & - & 6 & 10 & 9 \\
\hline
\end{tabular}

n. a. : not analysed 
Table 8 Descriptive statistics for the trace elements total concentrations of the data set from the French and Walloon inland sediments monitoring networks

\begin{tabular}{ccrccc}
\hline $\begin{array}{c}\text { Trace } \\
\text { element }\end{array}$ & $\begin{array}{c}\text { Number of } \\
\text { samples }\end{array}$ & $\begin{array}{c}\text { Max. } \\
(\mathrm{mg} / \mathrm{kg})\end{array}$ & $\begin{array}{c}\text { Median } \\
(\mathrm{mg} / \mathrm{kg})\end{array}$ & $\begin{array}{c}\text { Threshold } \\
\text { conc. }(\mathrm{mg} / \mathrm{kg})\end{array}$ & $\begin{array}{c}\text { Substance considered } \\
\text { CRM category }\end{array}$ \\
\hline As & 3348 & 1005 & 6.7 & $\geq 216$ & PbHAsO $_{4} ; \mathrm{C} 1$ \\
$\mathbf{C d}$ & 4012 & 7285 & 0.8 & $\geq 778$ & $\mathbf{C d S} ; \mathrm{C} 2$ \\
$\mathbf{C o}$ & 1104 & 2490 & 10 & $\geq 495$ & $\mathbf{C o C O}_{3} ; \mathrm{C} 2$ \\
$\mathbf{C r}$ & 3443 & 750 & 37 & $\geq 161$ & PbCrO $_{4} ; \mathrm{C} 1$ \\
$\mathbf{N i}$ & 3994 & 2380 & 19.2 & $\geq 494$ & NiCO $_{3} ; \mathrm{C} 1$ \\
$\mathbf{P b}$ & 3996 & 50420 & 34 & $\geq 597$ & PbHAsO $_{4} ; \mathrm{C} 1$ \\
$\mathbf{Z n}$ & 3412 & 142500 & 148 & $\geq 361$ & $\mathbf{Z n C r O}_{4} ; \mathrm{C} 1$ \\
\hline
\end{tabular}




\section{Figure captions}

Fig 1 Scattergram of $\mathrm{Cr}, \mathrm{Pb}$ and $\mathrm{Zn}$ concentrations from the French marine sediments monitoring networks. The full line around the centre of the distribution is the median, while the dashed line corresponds to the threshold concentration

Fig 2 Scattergram of $\mathrm{As}, \mathrm{Cd}, \mathrm{Co}, \mathrm{Cr}, \mathrm{Ni}, \mathrm{Pb}$ and $\mathrm{Zn}$ concentrations in the sediments from the French and Walloon inland monitoring networks. The full line around the centre of the distribution is the median, while the dashed line corresponds to the threshold concentration. The white cross is the mean value

Fig 3 Linear correlation between samples with $\mathrm{Cr}>161 \mathrm{mg} / \mathrm{kg}$ and the $\mathrm{Zn}$ concentrations in the corresponding samples from the French and Walloon inland monitoring networks

Fig 4 Linear correlation between samples with $\mathrm{Zn}>361 \mathrm{mg} / \mathrm{kg}$ and $\mathrm{Cr}$ concentrations in the corresponding sediments samples from the French and Walloon inland monitoring networks

Fig 5 Linear correlation between samples with $\mathrm{Pb}>597 \mathrm{mg} / \mathrm{kg}$ and the $\mathrm{Cr}$ concentrations in the corresponding sediment samples from the French and Walloon inland monitoring networks

Fig 6 Linear correlation between samples with $\mathrm{Cr}>161 \mathrm{mg} / \mathrm{kg}$ and the $\mathrm{Pb}$ concentrations in the corresponding sediment samples from the French and Walloon inland monitoring networks

Fig 7 Linear correlation between samples with $\mathrm{Pb}>597 \mathrm{mg} / \mathrm{kg}$ and the As concentrations in the corresponding sediment samples from the French and Walloon inland monitoring networks 
Figure 1
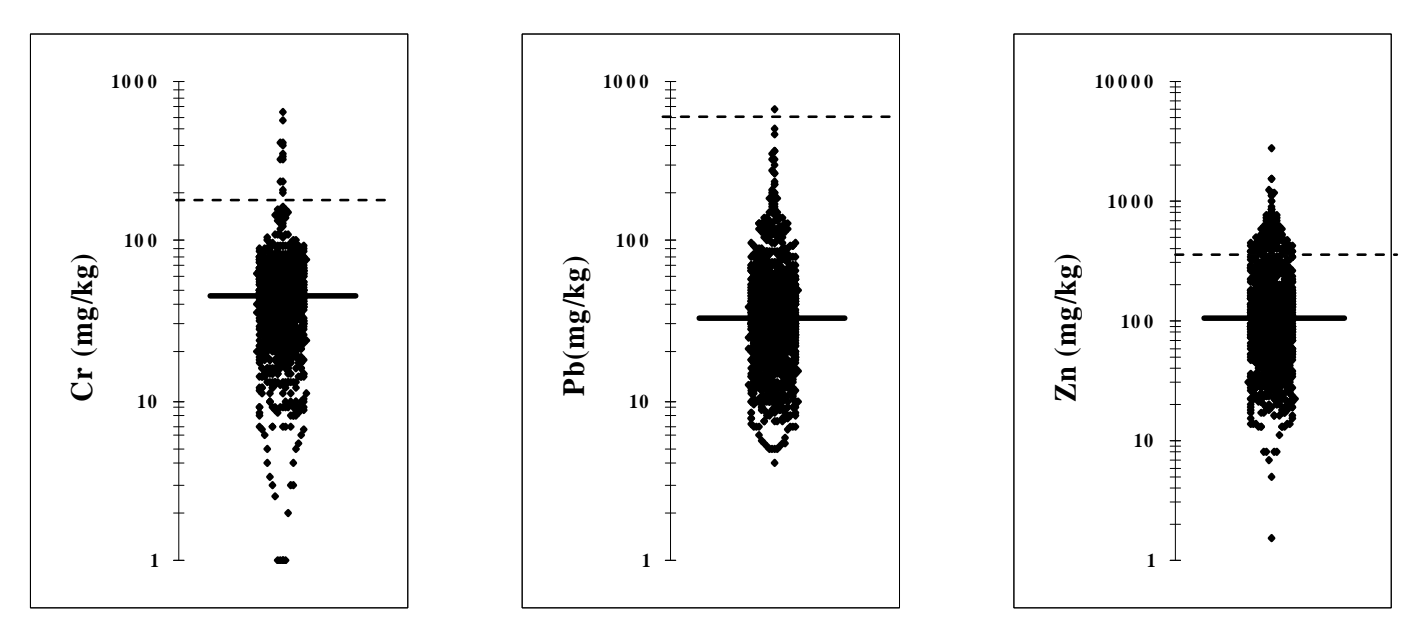

Figure 
Figure 2
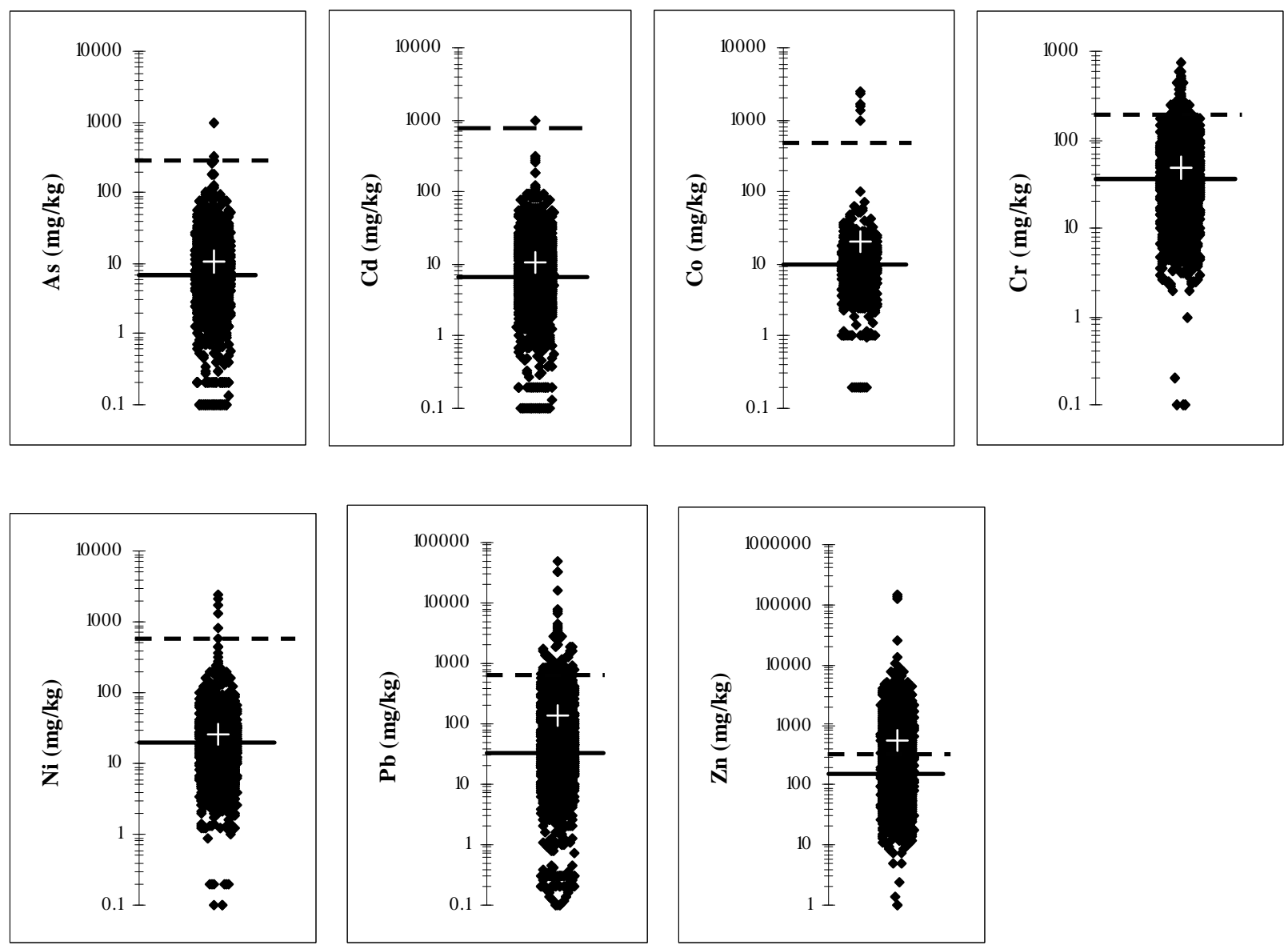
Figure 3

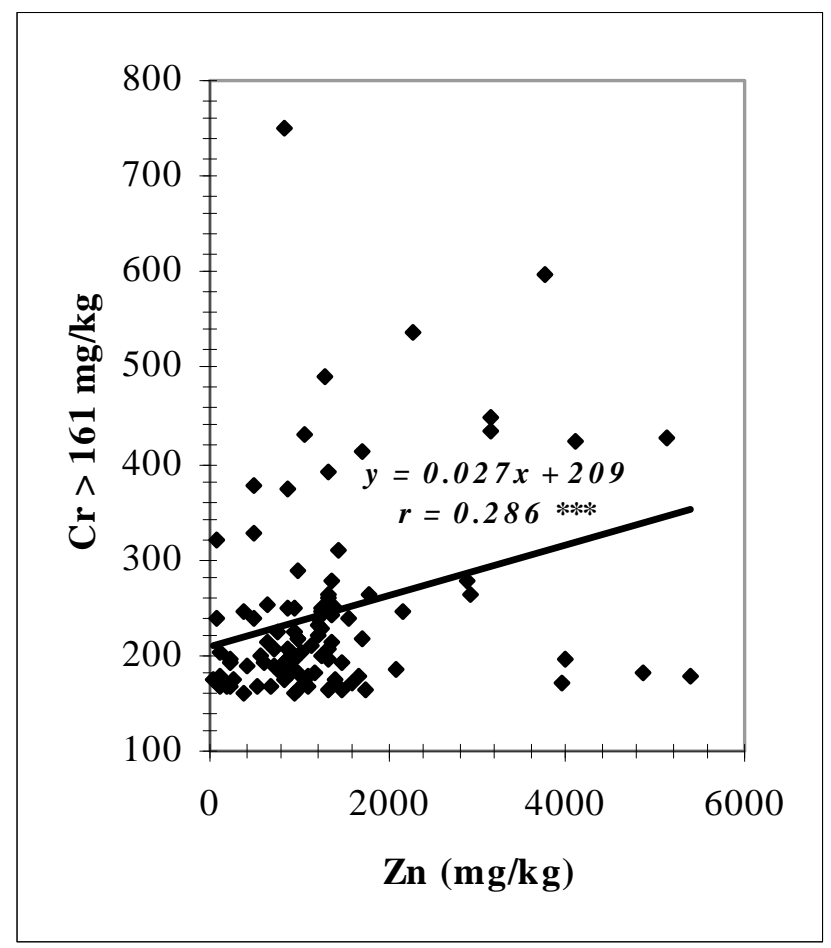




\section{Figure 4}

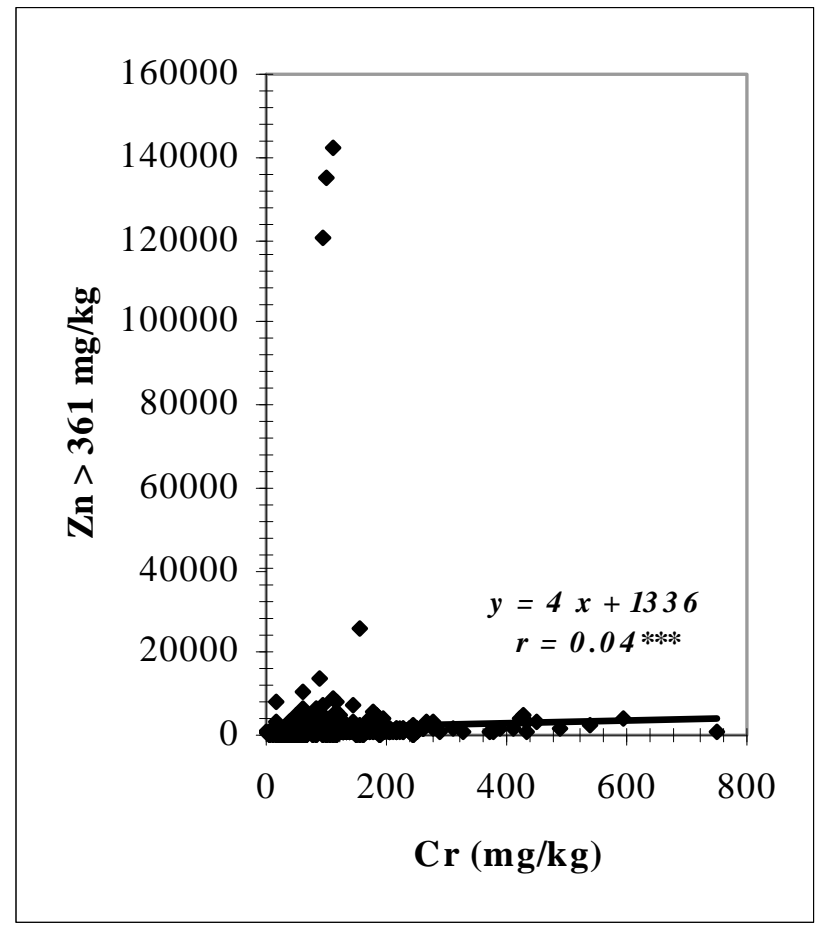


Figure 5

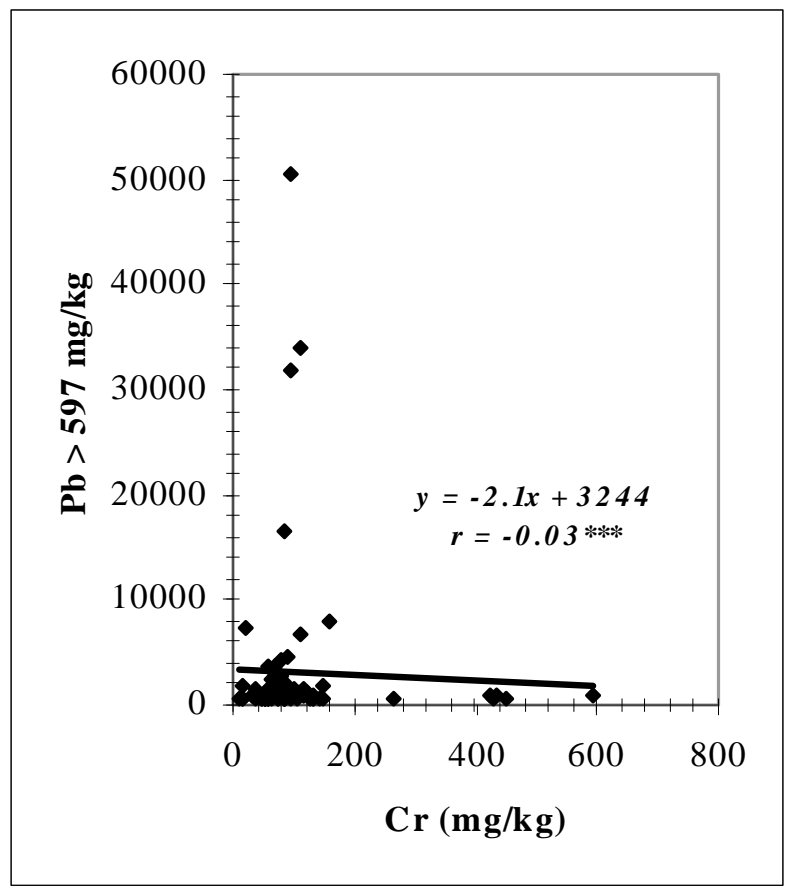


Figure 6

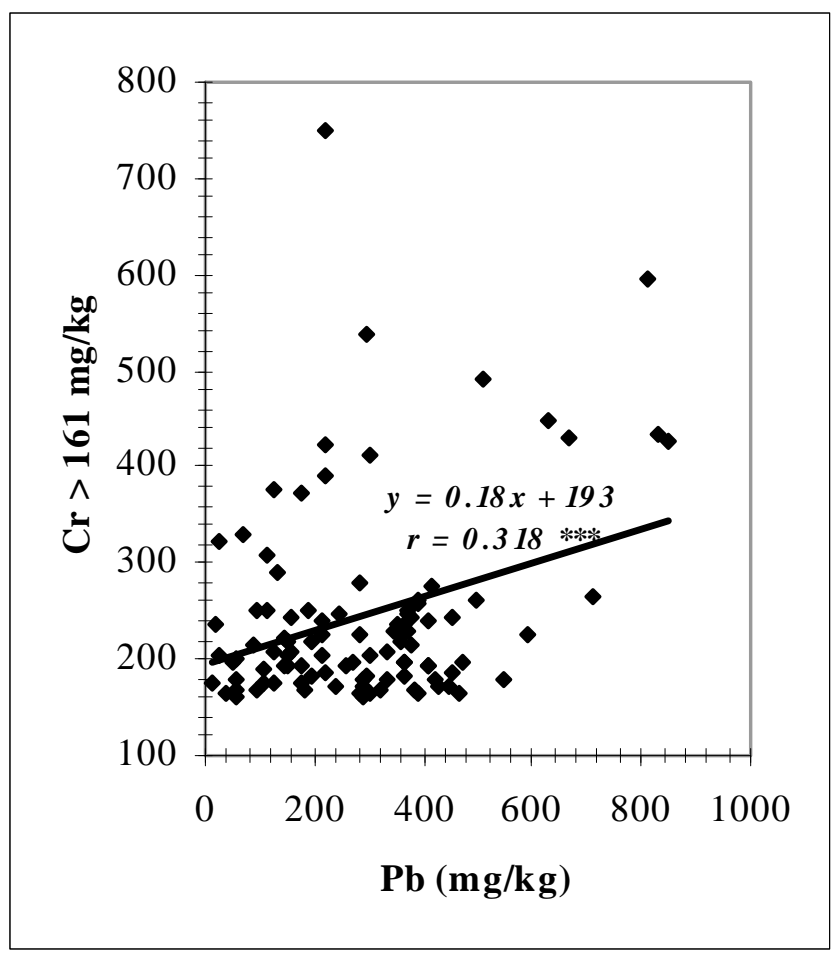


Figure 7

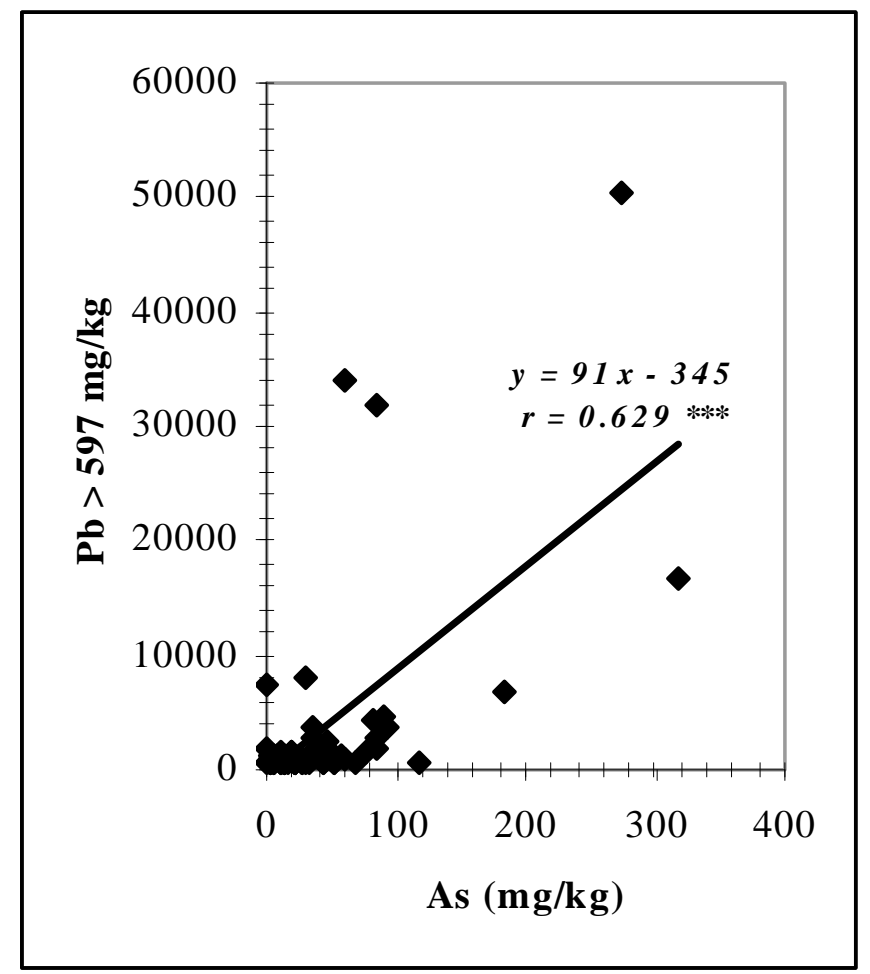


Supplementary Material
Click here to download Supplementary Material: On line supplementary information paper Mouvet_Tables $1 \& 2$.doc

Supplementary Material
Click here to download Supplementary Material: On line supplementary information paper Mouvet_Tables 1 \& 2.doc

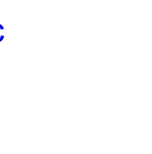

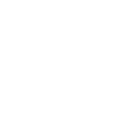
(1)

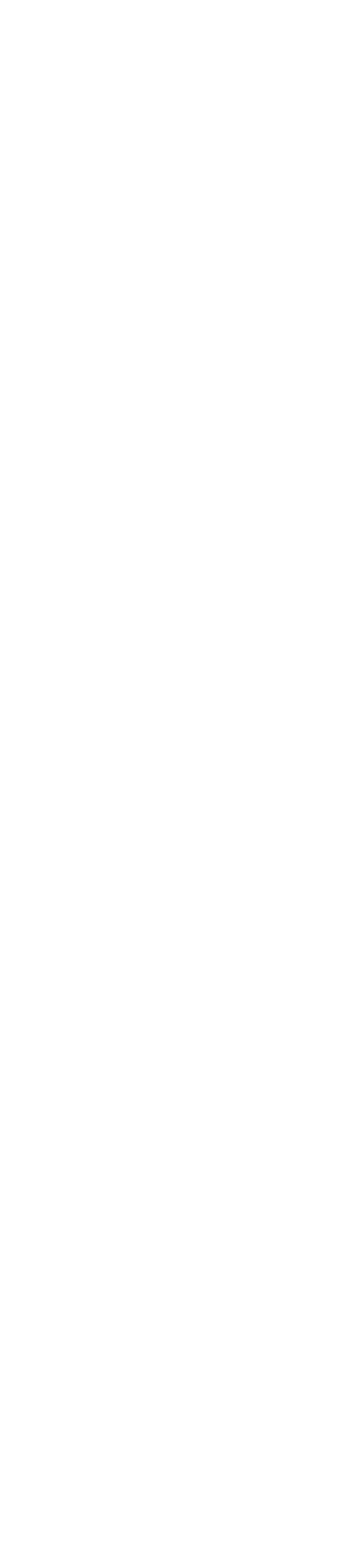

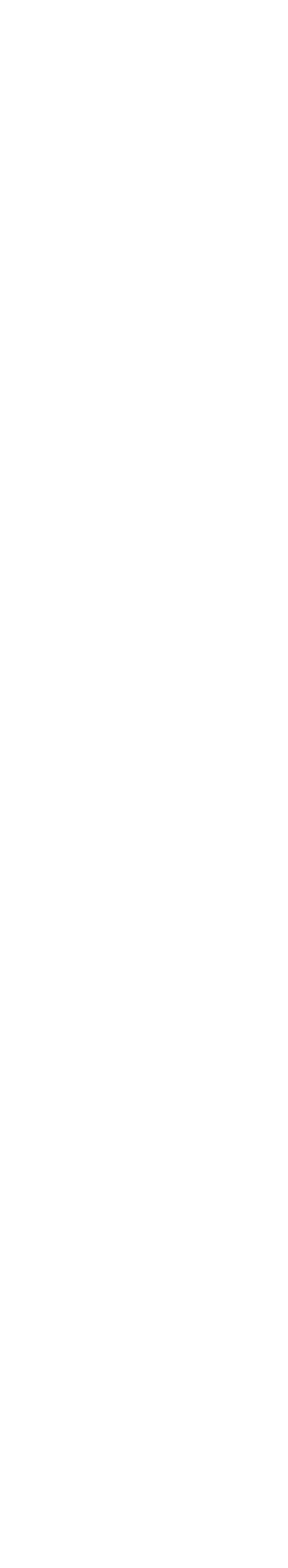

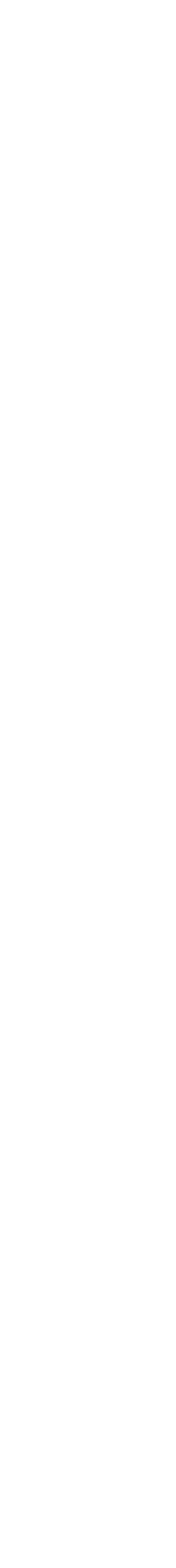

